Winter 12-31-2010

\title{
Towards a Critical Philosophy of Science: Continental Beginnings and Bugbears, Whigs, and Waterbears
}

Babette Babich

Fordham University, babich@fordham.edu

Follow this and additional works at: https://fordham.bepress.com/phil_babich

Part of the Continental Philosophy Commons, History of Philosophy Commons, and the Philosophy of Science Commons

\section{Recommended Citation}

Babich, Babette, "Towards a Critical Philosophy of Science: Continental Beginnings and Bugbears, Whigs, and Waterbears" (2010). Articles and Chapters in Academic Book Collections. 41.

https://fordham.bepress.com/phil_babich/41 
This article was downloaded by: [University of California, San Diego]

On: 23 February 2011

Access details: Access Details: [subscription number 929649504]

Publisher Routledge

Informa Ltd Registered in England and Wales Registered Number: 1072954 Registered office: Mortimer House, 3741 Mortimer Street, London W1T 3JH, UK

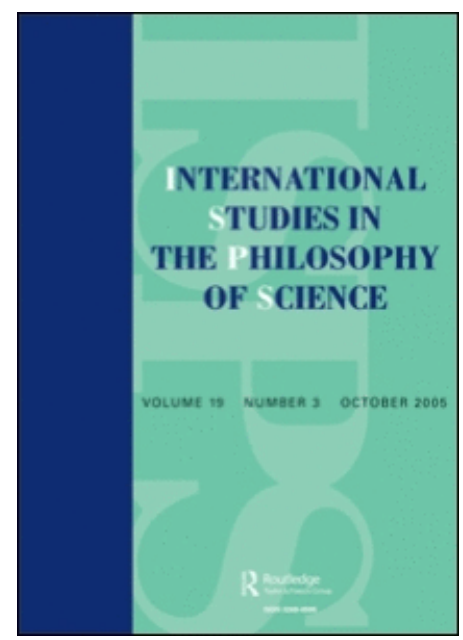

International Studies in the Philosophy of Science

Publication details, including instructions for authors and subscription information:

http://www.informaworld.com/smpp/title $\sim$ content=t713427740

\section{Towards a Critical Philosophy of Science: Continental Beginnings and} Bugbears, Whigs, and Waterbears

Babette Babich

Online publication date: 18 February 2011

To cite this Article Babich, Babette(2010) 'Towards a Critical Philosophy of Science: Continental Beginnings and Bugbears, Whigs, and Waterbears', International Studies in the Philosophy of Science, 24: 4, 343 - 391

To link to this Article: DOI: 10.1080/02698595.2010.543349

URL: http://dx.doi.org/10.1080/02698595.2010.543349

\section{PLEASE SCROLL DOWN FOR ARTICLE}

Full terms and conditions of use: http://www.informaworld.com/terms-and-conditions-of-access.pdf

This article may be used for research, teaching and private study purposes. Any substantial or systematic reproduction, re-distribution, re-selling, loan or sub-licensing, systematic supply or distribution in any form to anyone is expressly forbidden.

The publisher does not give any warranty express or implied or make any representation that the contents will be complete or accurate or up to date. The accuracy of any instructions, formulae and drug doses should be independently verified with primary sources. The publisher shall not be liable for any loss, actions, claims, proceedings, demand or costs or damages whatsoever or howsoever caused arising directly or indirectly in connection with or arising out of the use of this material. 


\title{
Towards a Critical Philosophy of Science: Continental Beginnings and Bugbears, Whigs, and Waterbears
}

\author{
Babette Babich
}

Continental philosophy of science has developed alongside mainstream analytic philosophy of science. But where continental approaches are inclusive, analytic philosophies of science are not-excluding not merely Nietzsche's philosophy of science but Gödel's philosophy of physics. As a radicalization of Kant, Nietzsche's critical philosophy of science puts science in question and Nietzsche's critique of the methodological foundations of classical philology bears on science, particularly evolution as well as style (in art and science). In addition to the critical (in Mach, Nietzsche, Heidegger but also Husserl just to the extent that continental philosophy of science tends to depart from a reflection on the crisis of foundations), other continental philosophies of science include phenomenology (Husserl, Bachelard, Merleau-Ponty, etc.) and hermeneutics (Heidegger, Gadamer, Heelan, etc.), especially incorporating history of science (Nietzsche, Mach, Duhem, Butterfield, Feyerabend, etc.). Examples are drawn from the philosophy of sciences (chemistry, geology, and biology) other than physics.

God exists since mathematics is consistent, and the Devil exists since its consistency cannot be proved.

-Hermann Weyl

\section{On the Perils of Critique, or Using Nietzsche to Distinguish Analytic and Continental Philosophies of Science}

'Continental philosophy' reflects a distinctive kind and style of philosophizing (Boundas 2007, 367) rather than specifying a geographic locale (West 1996, 6). ${ }^{1}$ Continental philosophy of science likewise represents a distinctive approach to philosophy of science

Babette Babich is at the Department of Philosophy, Fordham University. Correspondence to: Department of Philosophy, Fordham University, 113 W. 60 ${ }^{\text {th }}$ Street, New York, NY 10023, USA. E-mail: babich@fordham.edu 
but the locative reference lends itself to the tactics of denial and confusion that have become routine when speaking of the analytic-continental division in philosophy (Babich 2003a). Proximally this is because mainstream or analytic philosophy of science originated on the continent in the logical empiricism or positivism of the tradition of the Vienna Circle and was subsequently established in English-speaking philosophical centres by (originally) European scholars. ${ }^{2}$ It should go without saying that such origins do not make traditional, analytic philosophy of science a 'continental' tradition (although this is how amphiboly works). It should also go without saying that some authors, like Barry Smith ${ }^{3}$ and Kevin Mulligan ${ }^{4}$ but also like Brian Leiter more broadly, take this history to justify the claim that analytic philosophy is continental philosophy, a claim which supports the parallel assertion that what is usually named continental philosophy just isn't philosophy. Continuing the operative equivocation, we are informed that the best 'continental' philosophy is that work done by analytically trained philosophers. ${ }^{5}$ Contradictory or not, such discriminative evaluations work, as comparative machinations always function, under the mantle of enlightenment and 'better knowing' and thus in perfect good conscience, especially in the case of Nietzsche, but also with reference to Heidegger and others. ${ }^{6}$

Beyond the co-opting efforts of gate-keeping exclusion (excluding other voices and approaches, while claiming to be the real authority on such), the tradition of continental philosophy, as I speak of it in what follows, represents a range of approaches to philosophy including the philosophies of science. ${ }^{7}$ I count critical (Nietzsche), phenomenological (Husserl), and hermeneutic (Heidegger but also Husserl) philosophies of science among more recent representatives and developments.

I concentrate on Nietzsche's critical philosophy of science although I could also have focused on Ernst Mach and others such as Gaston Bachelard. Significantly, however, the reception of Mach in the philosophy of science, and to a lesser degree Bachelard's, has been more analytic than continental (as I am using the term here) and thus both Mach and Bachelard have been the subject of more than one renaissance. Alternately, I might here have focused on Neurath or else on Cassirer and for a more esoteric concern, but one specifically related to mathematics, Becker or Heidegger. ${ }^{8}$ Yet Nietzsche is a recalcitrant figure in philosophy of science and philosophers have been slow to note even the extent of the relationship between Nietzsche and Kant (let alone Nietzsche and Mach) leaving this discussion to historians of ideas and other source scholarship. ${ }^{9}$ More slowly still, Nietzsche scholars have begun to advert to the significance of Nietzsche's philosophical reflections on science. ${ }^{10}$ However, and inasmuch as the focus on Nietzsche's epistemology has tended to be indistinguishable from readings of the nihilistic dangers of his thinking, ${ }^{11}$ Nietzsche is not regarded as a philosopher whose thinking bears on science at all-much less philosophy of science. ${ }^{12}$ Instead and at best, i.e., where his name is mentioned in analytic or mainstream philosophy of science (and it rarely is), Nietzsche is usually taken to represent the 'Dionysian' element in science (Holton 1978), ${ }^{13}$ a happenstance further complicated by a parallel tendency to claim him, as those Nietzsche scholars who write on Nietzsche and science do, as an uncritically pro-scientific thinker, keen on science yet hard on 'scientism'. 
Such contradictory readings are effective just where Nietzsche is presumed to permit any and all interpretations, enhanced by the analytic expedient of stipulating inconvenient bits as 'confused' (Babich 2003a, 2007a). But the problem lies in our conviction that we are well able to distinguish science and scientism, as Tzvetan Todorov critically underscores the monolithic power of science deriving from the metaphysical 'hypothesis that the real world is an entirely coherent structure... [and] ... can be known entirely and without residue by the human mind. The task of acquiring such knowledge is delegated to the requisite praxis, called science. No fragment of the material or spiritual world ... can ultimately resist the grasp of science' (Todorov 2003, 19-20). Tom Sorrell, similarly opposing well-disseminated claims that science somehow suffers from a lack of esteem in today's world, warns that the problem is not to 'create respect for science but to dissuade people from worshipping it' (Sorrell 1991, 177). For Todorov, the problem is that same adulation of science from the scientistic point of view and given the positivistic conviction that there is 'no room for more than one version of scientific truth; errors are many, but the truth is one, and so pluralism becomes irrelevant' (Todorov 2003, 21).

The conviction that Nietzsche liked science but disliked scientism, neat as this would be if it could be defended, misses the critical element of Nietzsche's philosophy of science and fails to pose the question Nietzsche famously (or infamously) regarded himself as having been the very first to pose: namely of being the first thinker to raise the question of science as such (Babich 1994, 36). A discussion of Nietzsche's philosophy of science must attend to this question in the context not of what Nietzsche might have known about science or whether he was for it or against it but of the philosophy of science proper. But, and hence the rampant science anxiety such reflections inspire, to read Nietzsche as a philosopher of science is to confront the limitations of traditional and contemporary philosophy of science (Babich 1994, 1). On the other hand, as it may be argued, Nietzsche's philosophical reflections on science also provide the foundations for any critical theory of science that can come forth and endure as a properly philosophical philosophy of science (Babich 2010a, 1; cf. Babich 1994, 35).

The question of foundations, a critical question in Nietzsche's time as in Husserl's and Heidegger's, is central to Nietzsche's philosophy of science, and he parses this question in his own discipline as the critical one of style and judgment. In addition, Nietzsche raises the question of method. In this way we may regard Nietzsche's philosophy of science as a radicalization of Kant's epistemology and philosophy of science. ${ }^{14}$ Raising the question of science critically, Nietzsche methodologically deploys the resources of art as a self-conscious and innocent illusion for 'the problem of science cannot be recognized in the context of science' (Nietzsche 1980, vol. 1, 13).

\subsection{Nietzsche's Homer Question and Darwin's Origin of Species out of the Spirit of Language}

As organized knowledge or especially as a learning or research process specifically concerned with the empirical, i.e., both natural and social worlds, science is routinely presumed a matter of method and systematizing, well-ordered, and quantifying 
analysis. In the context of his early reflections on his first book on Greek tragedy and art, what Nietzsche called 'the problem of science' (Nietzsche 1980, vol. 1, 13) asks after the specifically scientific character of science. Thus Nietzsche's science question asks: what makes science science? For this reason, Nietzsche's first book begins with the question of the science of aesthetics as a science and its progress as a science. For the same reason, Nietzsche's 1869 inaugural lecture in Basel articulates the science of classical philology as a discipline struggling against itself, a highly political struggle conceptually adumbrated by way of the very 'scientific' definition of philology as such. ${ }^{15}$ For our purposes here, it will help to recall Karl Jaspers' explanation of Nietzsche's critical question of science in terms of its specifically scientific methodology (Jaspers 1997, 172ff.). 'Method' itself-which Nietzsche here invokes as securing a critically decisive certainty for historical and text-critical critique ${ }^{16}$ — refers to the very specific internally self-referential and so inherently self-constating basis of philological-historical or genealogical texts- and text-focused research, beginning with Karl Lachmann, usually regarded as the originator of the philological method ${ }^{17}$ of text criticism, ${ }^{18}$ and thence to Friedrich Ritschl and of course beyond and even to our day. Lachmann's method of textual criticism, originally applied by Lachmann to the editing of classical and particularly to medieval texts, has continued for years to be of interest in medieval and renaissance scholarship (Kristeller 1981), including, recently, the growing interest in the role of Lachmann's method and the history of scientific classification (Ginzburg 2004) and the relation between stemmatics and cladistics (i.e., between philology and evolution). Thus in The Origin of Species, Darwin suggests, not at all in passing but rather at some length, that it 'may be worthwhile to illustrate this view of classification, by taking the case of languages' (Darwin 1864, 367), ${ }^{19}$ an assignment duly taken up by the linguist August Schleicher (1873), a friend of the invertebrate zoologist (and socalled 'German Darwin'), Ernst Haeckel (cf. Richards 2002, 2008).

Tracing the connection between philology and the development of evolution, William Robins offers the importantly Nietzschean critique (Robins, a historian of science, manages not to credit Nietzsche at this juncture although he does mention him subsequently) that the genealogical method of textual criticism, as the historical-critical method and qua epitome of scholarship

depended on editorial judgment about which readings were 'errors' and which were
not. This difficulty has always been the biggest practical obstacle for the Lachman-
nian method- different editors of the same tradition could disagree about even the
most basic decisions. The identification of errors, even of apparently egregious ones,
is a matter of competent, intuitive, and ad hoc deduction, and accordingly varies
considerably from one critic to the next. (Robins 2007, 92)

The point Robins makes here echoes the central issue of Nietzsche's inaugural lecture on the Homer question. This is the critically didactic reason why classical philologists such as Helmut Flashar but also Hugh Lloyd-Jones and William Arrowsmith, who dedicated an issue of the classics journal Arion to this recommendation, urged that philologists attend to Nietzsche's critique of philology quite specifically as a science (Arrowsmith 1974 [1973]). If Robins, to be sure, goes on to refer to Nietzsche he seems unaware of Nietzsche's own critically reflexive arguments. ${ }^{20}$ 
For his part, like the science question he would later spell out in his 1886 preface to the first book on tragedy, Nietzsche poses the Homer question, as a question in his 1869 inaugural lecture. Framed as a question of specifically 'aesthetic' judgement, or taste, thus conceiving the issue as one between literary transmission and individual invention and a collective tradition of oral composition, Nietzsche's challenging argument is that it is a 'stylistic' or 'artistic', i.e., a very specifically aesthetic confidence that underlies all traditionally philological conclusions. However one opts to resolve the Homer question - that is: no matter what position one takes - the scholar assumes in each case 'that the problem of the present form of these epics can be solved from the standpoint of aesthetic judgment' (Nietzsche 1994, 296). Hence, Nietzsche observes, every foray into the question of Homer, resolving the issue one way or the other turns out to reproduce 'nothing other than a series of beautiful and prominent loci, selected in accordance with subjective taste' (subjektiver Geschmacksrichtung) (Nietzsche 1994, 299).

In other words, making a judgement on the Homer question as a whole or merely on the status of a word, a phrase, the philological scholar simply expresses his own 'subjective taste' (ibid.). That is to say, as Nietzsche observes, 'the epitome of aesthetic singularity which each individual scholar identified according to his own artistic capacity, he now designates as Homer' (ibid.).

Invoking the philologist's ability to discriminate styles, Nietzsche reminds us that this expert ability rests upon nothing more methodic than aesthetic judgment. Thus Nietzsche reminds us that the designation of 'Homer as composer of the Iliad and the Odyssey is no historical tradition but an aesthetic judgment' (ibid.).

Nietzsche never abandons this insight into the aesthetic and thus subjective basis of philology and arguably of science as a whole, and he begins The Birth of Tragedy by invoking the 'science of aesthetics' (aesthetische Wissenschaft). As a science of judgment and that also means of institutionalized taste, philology depends upon the expert ability to discriminate and attribute styles. It is relevant to Nietzsche's point here that beyond philology, the theoretical or 'scientific' study of art also deploys the same stylistic terminology. ${ }^{21}$ This is that same 'science of aesthetics' invoked in the very first line of the Birth of Tragedy (Nietzsche 1980, vol. 4, 25).

As a rigorous scientific modality, the distinguishing stylistic judgment of 'the science of aesthetics' made the identification of kinds (of texts and authors, kinds of artists, artifacts and even kinds of cities) possible. It is thus hardly an accident that the judgement of 'style' is also the key to Nietzsche's fundamental critique of empirical and historico-archaeological no less than the text-based or hermeneutic dimensions of philological research, if we may here recall the disciplinary conflict classically attributed to the conflict between Friedrich Ritschl and Nietzsche's other, and rarely discussed as such, teacher, Otto Jahn. ${ }^{22}$

In the tradition of Lachmann's method of text-criticism, Ritschl's school would be responsible for producing no fewer than 36 university professors and 38 instructors at the secondary level, among which Nietzsche would be counted as only one. ${ }^{23}$ And if Nietzsche's specifically methodic sensibilities may be traced to Ritschl's seminars, ${ }^{24}$ it is also relevant that Nietzsche's own philological education took place in the midst of 
the infamous Ritschl-Jahn dispute, giving Nietzsche a very literal schooling in the competitiveness of the academy. Nietzsche's later challenge to the historico-critical method would in turn grow out of this same intimate and formative agonistic experience inasmuch as Nietzsche interpreted this critical reflexivity on the basis of Lachmann's own rigorous sensibilities, just as Wilamowitz would later do, radicalized as the imperative to go further than Lachmann himself. For Nietzsche, this imperative would be articulated by way of a return to the sources of received text-critical methodology in the specifically genealogical legacy of the Homer question itself. ${ }^{25}$

Characterizing the exemplary application of such stylistic matters as a critique of scholarly judgment, Nietzsche's conceives the 'Homer question' in a tradition going back not only to Goethe and Schiller but the famed first philologist Friedrich August Wolf but (and this was Nietzsche's cardinal criticism) one that could also be traced back to the philological tradition of the Greeks themselves. As Nietzsche explains: 'the zenith of the historical-literary studies of the Greeks, and hence also of their point of greatest importance-i.e., the 'Homer question' — was reached in the age of the Alexandrian grammarians' (Nietzsche 1994, 291).

Beginning with a return to the ancient institution of a contest between Homer and Hesiod and thence to the role of Pisistratus (as Nietzsche emphasizes the agon), ${ }^{26}$ Nietzsche undertakes to highlight the standard Homer question as 'the question concerning Homer's personhood' (Nietzsche 1994, 290), that is to say: the question of the personal existence of Homer. And yet this very question was, let it be underscored, both in Nietzsche's day and before, a question long replete, as it still is today, with answers.

To say this in other words, the 'Homer Question' is not an actual question but and much rather a question long dissolved as such.

Nietzsche specifies the then 'effective "Homeric question"' by asking whether 'Homer's personality, because it could not be grasped, had gradually become attenuated to an empty name? Or had one then and in naïve folk fashion incorporated the entirety of heroic poetry, visualized under the figure of Homer?' (Nietzsche 1994, 293). As a formula, Nietzsche's expression of this question functions both on and as directed to the level of antiquity itself, regarding the level of its scholarly reception and critical interpretation. In this way, Nietzsche directs the question of 'personality' to antiquity as a question- 'Is a concept thereby created from a person, or a person from a concept?' (ibid.) — while he at the same time puts the academic profession of classical philology itself in question.

Functionally detailing a critique of scholarly (or as Nietzsche would say: scientific) philological judgement, Nietzsche's critically reflexive insight into philological classifications of style concerns the subjective role of taste. If Nietzsche himself takes a very specific position on the Homer question, emphasizing the oral tradition as he does (and as many classicists today, surprisingly enough, fail to do), the same subjective/ objective distinction includes a double allusion to the matter of judgement and taste in the question of Homer as such and the discipline of philology.

The point Nietzsche seeks to make here with regard to stylistic judgment and subjective taste is complicated. An illustration of what is at stake in the question of the 
objectivity of subjective taste is given in David Hume who also raised this question on the topic of what he called 'The Standard of Taste'. Hume, for his own part, points the question ironically enough citing Cervantes's illustration of the evaluative question of taste in his Don Quixote. ${ }^{27}$ Hume cites Cervantes as offering an objective exemplification of the same very subjective question of the very possibility of a standard measure of what one might call 'objective' taste:

It is with good reason, says SANCHO to the squire with the great nose, that I pretend to have a judgment in wine: This is a quality hereditary in our family. Two of my kinsmen were once called to give their opinion of a hogshead, which was supposed to be excellent, being old and of a good vintage. One of them tastes it; considers it; and after mature reflection pronounces the wine to be good, were it not for a small taste of leather, which he perceived in it. The other, after using the same precautions gives also his verdict in favor of the wine; but with the reserve of a taste of iron, which he could easily distinguish. You cannot imagine how much they were both ridiculed for their judgment. But who laughed in the end? On emptying the hogshead, there was found at the bottom, an old key with a leathern thong tied to it. (Hume 1965a, 282) ${ }^{28}$

Questions of objective nobility in a matter so patent as to be numerical (in Parker points or monetary value), the judgment of wine, good or bad, serves as a social indicator of class or nobility or wealth, as obvious in Cervantes's day as in Hume's (especially given Hume's education in wine less in Scotland than in the region of the Loire) as in our own. And an ability to discern good wine is behind the wine-pouring ritual (although this is arguably made more or less bootless with California-style controls: i.e., modern chemical additives, twist-off caps, and standardization).

The humorous illustration of Sancho Panza's kinsmen's good judgement coupled with the objective or literal confirmation of the same taste highlights Hume's exposition of the very problematic socio-cultural stakes of what Hume names the 'standard' of taste for the sake of distinguishing judgment or sentiment in his objective search for 'a rule by which the various sentiments of man may be reconciled; at least a decision afforded, confirming one sentiment and condemning another' (Hume 1965a, 282). ${ }^{29}$

As Nietzsche notes with regard to not to literal taste as in the matter of wine but aesthetic taste with regard to Homer, a particular and peculiarly, if specifically subjective presumption adumbrates the assumption 'that the problem of the contemporary circumstances of that same epic is to be solved using the standpoint of an aesthetic judgment' (Nietzsche 1994, 296). As Nietzsche poses it, this cuts to the heart of a scientific field based on subjective judgments of taste, judgments embracing the same objective considerations Hume adumbrates in his 'Of the Standard of Taste'. The philological scholar who forms a judgement on the Homer question as a whole or who comes to some insight on one question or another, or the scholar who merely resolves the status of a word or a phrase, each make a selection or a judgment on the basis of or expressing his insurmountably individual and hence all-too 'subjective taste' (Nietzsche 1994, 299). It is this same 'taste' that plays the decisive role, once again, now in context: 'What remained of Homer's own individual work? ... The epitome of aesthetic singularity which each scholar was capable of discerning with his own artistic gifts, he now named Homer' (ibid.). 
The classical scholar is presumed to be able to identify a fragment in terms of its style. Thus we demonstrate scholarly expertise. It is this empirical applicability and aesthetic substance that makes classical philology a science, much like archaeology and like art history. Nietzsche accordingly argues that the role played by style is scientific in the same way that Hume's sceptical question raises the question of taste in terms not only of subjective esteem but objective confirmation, and it is exactly this assessment of objectivity that Nietzsche challenges. ${ }^{30}$ Wine flavours and olfactory notes are described with language referring to hints and tastes of elements- tobacco, vanilla, oak, flintdistant from wine. This indeed is the specific tension brought out by the acuity of Sancho's relatives whose 'reserve of a taste of iron' turned out-'upon emptying the hogshead' - to have had a perfectly objective literality and at the same time, Hume's reference to Cervantes is importantly ironic.

The scope of the debate concerning the philologically quintessential Homer question, the point we recall at which Nietzsche seeks to go beyond Lessing's Laokoon in his inaugural lecture, can thus hardly be limited, as some argue, to his fascination with Wagner or anything other than Lachmann's text-critical method and the science of philology as such and in its most rigorous expression. From the start, Nietzsche's scientific concern was with the 'oral tradition' and the philologist's access to that same tradition.

The artistic role of the science of philology is not the role of the artist, composer or inventor (Nietzsche 1994, 304). Instead and at best, the practice of philology is a kind of playing or enactment: the philologist is, again and at his best, a virtuoso capable of singing the 'music' of antiquity to life again and hence and thus and 'for the first time to let it sound again' (ibid.). Thus Nietzsche's inaugural lecture offers advance notice of the very dynamic and very radical heart of his first book, The Birth of Tragedy out of the Spirit of Music (we have yet to begin to engage his claim as philosophers-and the philologists are further still from such an engagement). ${ }^{31}$

It was of course and in several senses, a book that should have sung and not spoken and Nietzsche's resolution of the question of tragedy was inherently musical (Nietzsche 1980, vol. 1, 140ff., esp. 143), literally so-in the words themselves-and figuratively, as 'musical dissonance' (ibid., 152), 'becoming human' (ibid., 155), as he spoke of it in his conclusion.

Nietzsche's question concerning style in his inaugural lecture, and indeed and it is not irrelevant, Hume's question concerning the standardization of taste (good and bad) could be rephrased for the purpose of the science of aesthetics in classical philology as in art and indeed in science. ${ }^{32}$

How, and we may well ask this in the wake of Fleck or Kuhn, are styles canonized? How are styles recognized to begin with? Nietzsche argues that style functions on the basis of so many pre-given canonic registers of taste, both collective and individual. The result projected in the case of the question of Homer, the individual poet, the 'personality' of the same, yields the very specifiable, very identifiable identity of the author, in this case Homer.

As a science of institutionalized taste and tasting, philology, like archaeology, is the expert school for the authorized ability to identify styles, locating ancient texts in their 
chronological context and similarly differentiating between ancient artifacts, and above all certifying the same-what, to be sure, do we need experts for if not certification? This, after all, is how archaeological and textual discoveries are made.

But, and this is the tension at work in Nietzsche's lecture, by invoking the philologist's ability to discriminate styles, Nietzsche's critical point (and it is this same critical point that leads Nietzsche to remark to his friend and philological colleague, Ernst Rohde of his inevitable disciplinary 'trepidation' ${ }^{33}$ or anxiety in this regard) is that this ability is founded upon nothing more exactly or methodically 'scientific' than aesthetic judgement as such, taken with all its strengths and all its weaknesses.

Nietzsche never abandons this stylistic insight into the fundamentally aesthetic basis of philology and accordingly as the foundation of science as a whole. Thus Nietzsche begins The Birth of Tragedy by invoking the 'science' of aesthetics as such and in his Thus Spoke Zarathustra Nietzsche thus recalls both his inaugural lecture as well as the beginning emphasis of his first book as he cautions his readers, here echoing Hume's 'standard' of taste as much as Kant's critical philosophy of the power of judgement: 'But all of life is a struggle of taste and tasting' (Nietzsche 1980, vol. 4, 150). ${ }^{34}$

Nietzsche makes the point that the classificational outlines of the ancient grammarians continues to frame the modern science of philology. And it is not irrelevant, as noted above with reference to Darwin, that philology likewise plays a role in both the linguistic designations, and so the scientific expanse of as well as the methodology of the sciences. ${ }^{35}$ Philology, classical and modern, here like art history and history more broadly, depends thereby upon the expert ability to discriminate and attribute styles. Here it matters especially with reference to art history that the theoretical or 'scientific' study of art flourished in the same period. Importantly, Nietzsche was familiar with Gottfried Semper's work on style (1860-63) which detailed the range of disciplines Nietzsche identifies as essential to philology from the archaeological and historical to the scientific and the mathematical, which last Semper also spoke of as a very 'practical aesthetics'. ${ }^{36}$ Semper's influence also can be found in Nietzsche's 1869 Greek MusicDrama, particularly with Nietzsche's then and today still-cutting-edge opening reference to polychromy (Nietzsche 1980, vol. 1, 531; cf. vol. 7, 15).

\subsection{Method and Science}

Focusing on method as such, Jaspers emphasizes that Ritschl's seminar was known for this same very Lachmannian methodic orientation and included a range of 'nonphilologists, including even numerous medical men, [who] participated in it with a view to learning "method"' (Jaspers 1997, 30), which Jaspers goes on to explicate as 'the art of distinguishing the real from the unreal, the factual from the fictitious, demonstrable knowledge from mere opinions, and objective certainty from subjective preference' (ibid.). It was the articulation of method as the rigorous means to secure knowledge of what we can be said to know and of what must be acknowledged as [yet] unknown, that brought Nietzsche to his critical insight into the formal limits of science, ${ }^{37}$ an insight which ought, so I have argued, to be extended to the philosophy of science more broadly. ${ }^{38}$ 
Opposing those who claim to know, Nietzsche discounts even those who either desist from such a claim altogether or make only a 'qualified' claim to knowledge, a habit of modest insistence, of having one's cake and eating it too, common among today's academics and scientists: 'It is to me irrelevant whether someone today possessed of the modesty of philosophical skepticism or religious conviction asserts, 'The essence of things is unknown to me' or else another, more cavalier sort, the kind who has yet to learn sufficient critique and suspicion says, "To a great extent, the essence of things is unknown to me"' (Nietzsche 1980, vol. 12, 240-241). Even such diffident or qualified claims to knowledge, as Nietzsche objects, 'fancy themselves as knowing much too much by far' (ibid.). As a critically minded Kantian regarding claims to knowledge both positive and negative, Nietzsche reminds us in The Gay Science that 'We simply lack any organ for knowledge, for the "truth"' (Nietzsche 1980, vol. 3, 593). It was this disposition to knowing claims which served for Nietzsche as a commonality that he felt he shared with Mach, and, patently enough, it also echoes in the thinking of Paul Feyerabend. In a comparable spirit, Nietzsche's contemporary, the French mathematician and scientific polymath, Henri Poincaré likewise emphasizes the precisely critical importance of reflective questioning: 'To doubt everything or to believe everything are two equally convenient solutions; both dispense with the necessity of reflection' (Poincaré 1905, xxii).

For Nietzsche, what is at issue in raising the question of science qua science is not a celebration of what we call 'critical thinking' today (by which we mean an uncritically scientistic approach to truth as certain knowledge) but and much rather the true spirit of philosophical critique (and here Jaspers does not differ from Heidegger) and consequently of that genuinely philosophical critique of science which consistently raises the question of science as a question. Jaspers thus characterizes Nietzsche's critical 'problem' (Jaspers 1967, 172ff.) or question of science in terms of scientific methodology not as anti-scientific, as some persist in hearing the spirit of any critique, but much rather as genuine or authentic scientificity (see also Babich 2009a). This conception of genuine scientificity would be common to Husserl, Heidegger, Becker, and others but also the scientists Heisenberg and Chargaff in addition to the chemist Fritz Paneth (whom we discuss further below) and, for a contemporary example of a critically minded (without being any less mainstream) scientist, Richard C. Lewontin.

Nietzsche challenges those positivistic thinkers in his day (as he would challenge those in our own time who assume) that 'philosophy itself is critique and critical scienceand nothing besides!' (Nietzsche 1980, vol. 5, 143). For Nietzsche, as for Heidegger, it is incumbent on the thinker to be critical of the claims of critical thinking-critics, as Nietzsche reminds us, even critical scientists, are themselves no more than the 'tools' of the philosophers, and are thus 'far from being philosophers themselves' (ibid., 144).

In addition to a critique of the science of aesthetics, Nietzsche's The Birth of Tragedy also included a reflection on the critical limits of logic as well as a discussion of modern technology and its mechanized lifestyle. The same emphases recur in The Gay Science, Beyond Good and Evil, The Genealogy of Morals, Twilight of the Idols and even the Antichrist (Babich 2010c) and a philologist's concern with the constellation of modern mathematics and science occupies Nietzsche in connection with ancient science and its 
technological and mathematical achievements (often discussed under the rubric of the Alexandrian), from his first book until the end of his productive life. ${ }^{39}$

\subsection{Nietzsche and the Sciences: From Emprio-criticism to Ethnography, Cosmology, Chemistry, and Mathematics}

Empirio-criticism or critical positivism was influential in the tradition that crystallized in the Vienna Circle, evolving into what was characterized as the expatriate Austrian and German tradition that became analytic philosophy of science. But the earlier tradition also included a critique of ideology of all kinds, especially metaphysics but also materialism, and it was in this tradition that Richard Avenarius would publish his compendious Critique of Pure Experience. ${ }^{40}$ Avenarius was influential not only for Mach but also for Husserl. An exploration of the relation between Avenarius in addition to Mach on Nietzsche's empiricism (not be confused with what today's analytic philosophers name his 'naturalism') remains a project for further research, not only in terms of a roster of sources (shades of Lachmann) but contextualization or hermeneutic investigation. ${ }^{41}$

Other currents that would likewise require a hermeneutic or interpretive elaboration on the theme of Nietzsche and science in addition to the role of philology in science and philosophy of science, are those of French anthropology or ethnography, notably Marcel Mauss and his seminal 1924 essay on the gift (Mauss 1924), written for the Nietzsche scholar Charles Andler, and significant for both the young Georges Bataille, who would go on to develop an economic theory of social expenditure (La part maudite or 'The Accursed Share') that drew on Nietzsche's energetics of life and power (and joy) as well as, very differently, the Polish anthropologist, Bronislaw Malinowski (1993), who likewise incorporated the insights of Nietzsche's first book into his own ethnographic contributions.

The role of Nietzsche's philosophic reflection on science has also influenced the course of the social sciences through Max Weber, a connection that should itself inspire further reflection although this is hardly to suggest that there is anything like a shortage of studies on Nietzsche and Weber, offhand one notes Robert Eden, Mark Warren, and many others. ${ }^{42}$ Instead and to date what is lacking is a study dedicated to articulating a specifically Nietzschean philosophy of social science. ${ }^{43}$ But as in the case of Weber and science, what is missing is not a study of the conjunction of Nietzsche and this social science or that one but a philosophical reflection that would, to borrow Nietzsche's words, take things further.

More than the psychology or sociology and political or ethical theory of his day, Nietzsche himself drew upon and responded to the mathematical and natural scientific currents of his day, particularly physiology but also cosmology, chemistry, etc. In this context, we may note, and we will return to this below, that the same Poincaré noted above, whose theories of relativity paralleled Einstein's, would also propose a theory of recurrence on the basis of the self-same Second Law of Thermodynamics which inspired Nietzsche's own doctrine of the always already consummate eternal recurrence of the same. 
Nietzsche's critique of science as humanizing convention addresses the critical issue of foundations so significant for the sciences, including the mathematics of his day. Thus Nietzsche identifies the mathematization of nature with what he calls the 'humanization' of nature, challenging the very foundational possibility of empirical knowledge and thus of explanation in terms of mathematical/theoretical means: 'But how could we possibly explain anything? We operate only with things that do not exist: lines, planes, bodies, atoms, divisible time spans, divisible spaces. ${ }^{44}$ Again, we may cite Poincaré as he could seem to confirm Nietzsche's challenge by observing 'Mathematical theories do not have as their object to reveal to us the true nature of things; that would be an unreasonable claim' (Poincaré 1905, 211). We will return to the relevance of Nietzsche's foundational critique below.

Alwin Mittasch, the chemist and philosopher of chemistry who also authored several studies on Nietzsche and science, remarks that a certain anthropomorphization is not to be excluded even in the natural sciences: 'All natural knowledge is in its kind and with reference to its boundaries conditioned by the psycho-intellectual organization of the knowing person and hence cannot avoid certain traces of 'humanisation" (Mittasch 1952, 47) ${ }^{45}$ Mittasch is not paraphrasing, although he does not give the reference here for he takes the term 'humanisation' and its implications from Nietzsche who writes: 'It will do to consider science as an attempt to humanize things as faithfully as possible; as we describe things and their after-one-another, we learn how to describe ourselves more and more precisely' (Nietzsche 1980, vol. 3, 473).

Adding to Poincaré's strong conventionalism and its parallel with Nietzsche, the German-Hungarian physicist, Eugene Wigner raises a question that similarly resonates with Nietzsche's own foundational question concerning the anthropomorphic character of mathematics and hence of its relevance to nature in Wigner's essay on 'The Unreasonable Effectiveness of Mathematics in the Natural Sciences' ${ }^{46}$ A classic essay dating from 1895 offers an early and popular outline of this same question for philosophers and logicians. Lewis Carroll (Charles Lutwidge Dodgson), the mathematician author of Alice's Adventures in Wonderland, offers us an iteratively fundamental reflection on the foundations of logic (Carroll 1895), highlighting the importance of granting the so-called 'given' in an object illustration of the non-necessity of any 'compulsion' to do so. ${ }^{47}$

We have already referred to the intense reflection on the question of foundations in mathematics in Nietzsche's day, culminating, as it were, with Hilbert's program as articulated in 1900. In this context, it is important to underscore the contributions to Nietzsche scholarship of the mathematician Felix Hausdorff (writing under the pen name of Paul Mongré $)^{48}$ along with Hans Vaihinger, who writes on Nietzsche in 1902, as well as the Austrian geologist and philosopher of science, Walter Del-Negro, who wrote on Nietzsche's theory of knowledge, in addition to Alwin Mittasch, already cited, on Nietzsche's natural philosophy and chemistry, all neo-Kantian philosophers.

Nietzsche's thinking on science includes a recurrent reflection on the problem of causality, strikingly parallel to Hume's own critique. Exemplifying Nietzsche's injunction that it necessary to 'doubt more radically than Descartes', and to articulate a more critical critique than Kant's, Nietzsche observes (and modern cognitive science 
stands with Nietzsche on the level of our perception of causality) that 'we learn how to describe ourselves more and more precisely. ... The suddenness with which many effects stand out misleads us; actually it is sudden only for us. In this moment of suddenness there are an infinite number of processes that elude us' (Nietzsche 1980, vol. 3, 473). At the same time, Nietzsche asks, 'how should explanations be at all possible when we first turn everything into an image, our image!' (ibid.).

Highlighting Nietzsche's critique of science/mathematics as anthropocentric, Hausdorff emphasizes the very radical point Nietzsche makes at this locus: 'We lack a self-critique of science; judgements of art, of religion, of feelings about science are as many in number as they are useless. Maybe this is the ultimate fate of mathematics!' (Mongré 1897, 342). Accordingly, the last section of Mongré's/Hausdorf's collection of aphorisms is entitled 'Towards a Critique of Knowing' (Mongré 1897, 319-362). It is perhaps no coincidence, but the parallel has yet to be fully explored, that along with Mach it is, again, Poincaré who shares Nietzsche's philosophy of qualified scientific restraint or limitation. ${ }^{49}$ This scientific caution Nietzsche also shares with the otherwise perfectly mainstream William H. Newton-Smith $(1981,14)$ who names it 'pessimistic induction'.

Apart from the separate question of understanding 'the problem of science itself, science considered for the first time as problematic, as questionable' (Nietzsche 1980, vol. 1, 13), Nietzsche's self-avowed project of putting science itself in question, sets the critically scientific thinker in a no-man's domain without orienting horizon. So far from the Cartesian promise of an Archimedean foundation, where is the thinker to stand in order to raise the question of science? The paradoxes of arithmetic, geometry, relativistic and quantum physics, as well as those of self-reference in logic and set theory matched with the sheer audacity of putting logic as such or the very idea of science in question, as Nietzsche does, lead to still further foundational questions and there is no limit to such questions. ${ }^{50}$ Indeed, the philosophically critical problem of science regarded as a problem derives from science's own self-founding limit. And Nietzsche goes beyond raising the question of critical foundations and the concept of method and consequently extends his critique beyond his own discipline to natural sciences like physics and chemistry precisely in their mathematical articulation as such. ${ }^{51}$

But and recollecting the above reflection on the relation between the genealogical method of historical textual criticism and Darwin, Nietzsche's specific comments on Darwin $^{52}$ tend to be notoriously confusing to Nietzsche scholars and other commentators, inspiring some to find him pro- and others anti-Darwinist. Nietzsche himself alluded to Darwin either generally and as an emblem of scientific modernity or he railed against him and not merely, seemingly negatively. In addition to a passage entitled 'AntiDarwin' in Twilight of the Idols, Nietzsche can tease that the idea of survival of the fittest manages to leave out the mind altogether (and cleverness, for Nietzsche, trumps evolutionary 'fitness' without being any less 'decadent' for that): 'Darwin forgot intelligence (-that is English!), the weak have more intelligence. You must have need of intelligence [Geist] in order to acquire it' (Nietzsche 1980, vol. 6, 121). ${ }^{53}$ Accordingly, Nietzsche ranks Darwin along with Mill and Spencer as respectable mediocrities (Nietzsche 1980, vol. 5,196$)$. In a Nachlass note he clarifies the point just cited in a context that emphasizes 
his insight into the superiority of slave morality and thereby the irresistible efficacy of a slave revolt in morals: 'Only one type of human being, survives longer than "the day after tomorrow"', Nietzsche says ruefully, 'the incurably mediocre' (ibid., 216-217). ${ }^{54}$

A non-reflective and ahistorical reading of Nietzsche exemplifies what he would call a 'lack of science'-that is to say: a 'lack of philology' (ibid., 69), broadened to include history.

And our historical scientificity or methodological sophistication has indeed improved: we know better than an earlier tradition of historians (historians of ideas as much as historians of science) in the wake of recent sociological and anthropological studies of science and its technologies (Fleck 1979; Shapin and Schaffer 1985; Dear 1995; Principe 1998). And we are plainly just beginning such a re-evaluation of a received view on the 'genesis and development' of science. A contextual and historical clarification of science in Nietzsche's era is preliminary to any evaluation of Nietzsche and science, and in part this task is under way. But here our own prejudices get in the way and this is the bugbear in the title of this essay. Thus Linus Pauling's quip that the task of correcting past errors routinely reconstitutes contemporary versions of the same errors ('Wissenschaft ist Irrtum auf den letzten Stand gebracht').

The durability of what Butterfield called Whig (or presentist-below we note that this is far from a neutral alternative) sensibilities (or reflexes) corresponds to the extreme difficulty not merely of putting old or traditional values in question, but to do the one thing Nietzsche found essential to any scientific inquiry-that is, to put ourselves and our presumptions (our convictions) in question. As the anthropologists of culture, whether of other knowledge discourses, such as Fleck, Latour, ${ }^{55}$ Pickering, etc., or of other societies, such as Geertz, Levi-Strauss, etc., have learned to their pain (or better said: as they are still attempting to learn), one can mean to bring a neutrality to bear on one's studies (and one's subjects) and still and yet fail to apply it.

\subsection{Pierre Duhem: Ideology and the Medieval Foundations of Modern Science}

History of science would appear to be the locus of as many conflicts as philosophy of science and it is hardly an accident that the tendency in recent years has been towards increasing separation and even opposition. This is patent in the long and complicated century of debate on the work of Pierre Duhem in the prototypically scientific field of physical cosmology. ${ }^{56}$ On the received or analytic side of the history of science, it is well known that Duhem's famous theoretical underdeterminism was influential for Einstein (Howard 1990). But Duhem's role is far more direct and he was also the author of a key account of the story of Catholic science in the Middle Ages (and incidentally indeed also Islamic, see Lejbowicz 2004 and Ragep 1990, and Jewish, see in particular Freudenthal 1988 and 1993; see too Ruderman 1995). If contemporary analytic philosophy of science rests, implicitly or explicitly, on the crucial idea of the Scientific Revolution, it is exactly this foundation that would appear to be undermined by Duhem's 10-volume Le système du monde (Duhem 1959 [1913]) as a historical reading challenging modern science's conception of itself by explicit contrast with both the medieval and the ancient world. 
In our above discussion of Nietzsche we noted Nietzsche's claim that traditional assessments of the limited or primitive achievements of antiquity, particularly of ancient science and technology, are mistaken, ${ }^{57}$ and, instructively, recent scholarship supports Nietzsche's observation. ${ }^{58}$ But if ancient science tends to present an even more difficult challenge, most historians and philosophers of science are hard pressed to fit the conceptual traditions of medieval science into the developmental tradition of modern science. In the same spirit, Ludwik Fleck while underscoring the social differences between world contexts, emphasizes the absurdity of the modern conviction that medieval scientists did not make observations: 'It would be a sign of naiveté to think that a man of those days was asleep, and roused himself from his sleep only during the Renaissance' (Fleck 1979, 74). According with Duhem's continuationist point vis-à-vis the scientific revolution, Paul Feyerabend critiques the stubborn ahistoricism of the Vienna Circle: 'Vienna Circle shares with the enlightenment an exaggerated faith in the powers of reason and an almost total ignorance concerning its past achievements' (Feyerabend 1978, 59). ${ }^{59}$ For his part, Feyerabend was fond of challenging the ongoing presumption that supposes Aristotle as incapable of observation as his medieval heirs. For Feyerabend, as for Nietzsche, the remedy would require more historical sensitivity for the sake of science, as such sensitivity to history increases the scientific rigor of scientific historiography by adding (rather than eliminating) hermeneutics.

Prior to the Enlightenment, the 'achievements' of reason (to use Feyerabend's terminology above) were by no means nugatory. As Duhem details, Domingo de Soto (1494-1570) had described freefall 80 years in advance of Galileo in his 1551 commentary on Aristotle's Physics. ${ }^{60}$ What Duhem began in this account would become the basis for an important change in the history of science, as Jeanne Pfeiffer explains: 'Duhem exploited long-neglected sources and enlarged the body of knowledge concerned with scholastic mathematics and philosophy. He defended the thesis that, through an uninterrupted sequence of barely perceptible improvements, modern science arose from doctrines taught in the medieval schools' (Peiffer 2002, 30). ${ }^{61}$

It is thus significant that Butterfield's terminological expression of the Whig interpretation of history is often diluted to the religiously neutralized language of a 'presentist' interpretation of history. Similarly there has been a significant and overtly antiCatholic backlash to Duhem's work. ${ }^{62}$ There would seem to be more openness to mysticism in science (although this is not true for philosophy, as Bergson's fortunes will testify) than to Catholicism (or, we should add, faith in general), an opposition that has haunted the reception not only of Duhem's work but the entire history and philosophy of science. ${ }^{63}$

In truth it was less his faith, important as that was to Duhem the man, than it was his focus on philological scholarship that has made a difference for the history of science and such source scholarship, including a critique of scholarly methods or historical practices (what as noted above Nietzsche simply called 'philology' by which he understood the very rigorous or scientific procedure of the same $)^{64}$ cannot be approached without an open sensitivity to and reception of secondary literature. ${ }^{65}$ Thus J. D. Bernal (1901-1971), a firmly atheistic thinker, was influenced by Duhem's approach to the history of science as was Butterfield, and today in this same lineage in 
the by no means uncritical tradition of Duhemian historiography, we may also count Alistair Crombie (1994).

Duhem's 1903 discovery of themes from Leonardo's notebooks in a medieval manuscript (of one Jordanus Nemorarius) is a case in point. As one scholar notes, so far 'from seeing Leonardo as the forerunner of modern science, Duhem fairly rooted him in the then-hitherto unexplored context of late medieval scholastic thought' (Turner 1994, 141). Duhem's resulting three-volume study of Leonardo (Duhem 1906) attests to a further connection between Leonardo and Nicholas of Cusa. Using a metaphor borrowed from Nietzsche to speak of the Greeks' unique discoveries (Nietzsche 1980, vol. 1, 804), Ernst Cassirer draws our attention to the detail of Duhem's account of 'how Leonardo received a great number of problems immediately from the hands of Cusanus and how he took them up precisely at the point Cusanus had left them' (Cassirer 2000, 50). ${ }^{66}$ But and like the very mainstream reading of Drake on Galileo, many contemporary scholars today simply acknowledge the connection between Leonardo and medieval science but fail to credit either Duhem or his sources. ${ }^{67}$

An important side twist on the history of science critical for any future reflection on Duhem's contributions to the history of science beyond received religious traditions (and inspired in significant part by John Maynard Keynes's purchase of Isaac Newton's papers on alchemy, see Principe 2004), has been pioneered in the English-language tradition by Frances Yates and Betty Jo Teeter Dobbs. ${ }^{68}$ This history of science takes this account to the continent (to Valentin Rose in particular in addition to Boyle and Locke) as Lawrence Principe's locates the role of alchemy beyond science in philosophy as well as theology. Others too have explored the literary and experimental basis of the 'preludes' of science, here invoking Nietzsche's expression of our all-too-human 'taste' for occult and secret powers (Nietzsche 1980, vol. 3, 539), a proclivity that turns out to be less a hindrance than an indispensable cultivation not of the ideal or theoretical constructions of natural science but exactly practical techniques. ${ }^{69}$

For Butterfield, it will be keeping one's presentist presuppositions in mind that will make all the difference for the history of science and here, so I am arguing by extension, for the philosophy of science. ${ }^{70}$ Instructively, the point Butterfield makes in his 1931 The Whig Interpretation of History is as elusive as it is stylistically well articulated. One need only substitute 'scientist' for Butterfield's use of Protestant or Whig in his reflection that

to many of us the sixteenth-century Protestants or the whigs of 1800 seem much more modern than they really were, and even when we have corrected this impression by closer study we find it difficult to keep in mind the differences between their world and ours. At worst some people seem willing to believe that Luther was a modern Protestant fighting for a broader and more liberal theology against the religious fanaticism of Rome; although heaven itself might bear witness that it was anything but drove Luther to exasperation. (Butterfield 1931, 34-35)

Butterfield goes on to make the thoroughly consistent but nevertheless still conceptually dissonant claim that 'We shall see Protestant and Catholic of the sixteenth century more like one another and more unlike ourselves than we have often cared to imagine-each 
claiming that his was the one true religion upon which both church and society should exclusively be established' (ibid., 38-39).

Influential as it has been, Butterfield's terminology, namely of the 'whig' interpretation of history, continues to present difficulties - these are the bugbears of the title of the present essay ${ }^{71}$-many of which seem to echo the religious anxiety that speaks in Butterfield's illustration of 'enlightened' prejudice in the still persistent presumption that: "'When the Pope ruled England them was called the Dark Ages"' (ibid., 13). ${ }^{72}$

We have already noted that the history of science continues to tend toward 'leaving things out', ${ }^{73}$ perhaps in the interest of minimizing complexity, which may be why contemporary history of science prefers to speak of 'presentism' rather than the 'Whig interpretation'. And yet the language of 'presentism' exemplifies the very problem of presentism as such and as Butterfield explains: 'The theory that is behind the Whig interpretation - the theory that we study the past for the sake of the present-is one that is really introduced for the purpose of facilitating the abridgment of history; and its effect is to provide us with a handy rule of thumb by which we can easily discover what was important in the past, for the simple reason that, by definition, we mean what is important "from our point of view" (ibid., 24).

\section{The Case for $-\mathbf{P}$ Philosophies of Science, where $\mathbf{P}=$ Physics}

Beyond critical philosophies of science like Nietzsche's as discussed above, continental philosophies of science include phenomenological philosophies of science like Husserl's and hermeneutic-phenomenological philosophies of science like Heidegger's and like Merleau-Ponty's (see Babich 2010d). In addition to Bergson and Mach, additional trends in continental thinking on the philosophy of science can also be seen as already observed, in the work of Duhem and in Poincaré (see Zahar 2001)—where it matters very much indeed that authors such Mach, Duhem, Poincaré and Bachelard are usually read in accord with analytic philosophy of science. To these very mainstream names we may add others such as Bergson, Weyl (see Kerszberg 1986), Planck, Schrödinger, ${ }^{74}$ and Cavaillès among others such as Bohr, etc., in addition to Heisenberg. ${ }^{75}$ Of these philosophically challenging thinkers, Heisenberg may well be the most philosophically challenging and as yet there have only two monographs dedicated to Heisenberg's philosophy of science. ${ }^{76}$ Ironically, far more attention has been paid to Bachelard in mainstream philosophy of science. ${ }^{77}$ And to the extent that a glamorization of science is not antithetical to contemporary culture, it is worth reflecting that Bachelard's mythification of science as a poetizing venture has proven to be less conceptually dissonant to mainstream philosophy than his Marxist epistemology. ${ }^{78}$ Indeed, Marxist approaches to the philosophy of science have had increasingly to struggle for recognition despite not only a long-standing presence in mainstream philosophy of science but not less owing to a resolutely and deterministically quantificational approach to science as such. ${ }^{79}$ If analytic philosophy of science excludes Nietzsche, Husserl, and Heidegger, as well as Engels and Lenin not to speak of Marx, it tends accordingly to ignore those authors who write philosophy of science, especially of biology and ethology from such perspectives. ${ }^{80}$ What highlights this exclusion as an ideological one is that dialectical 
materialist approaches to science and philosophy of science offer resolutely positive critiques of science rather than the more negative critiques associated with either Nietzsche or Heidegger.

Thus it is worth adverting once again to the distinction between continental and analytic styles of philosophy of science. For continental philosophies of science tend not to presume to represent the whole of 'philosophy of science'. ${ }^{81}$ By contrast, analytic philosophies of science tend to suppose their approach to be the only viable way to do what analytic philosophers call 'good' philosophy (anything else, as we saw at the outset, is excluded in advance as what 'isn't' philosophy) ${ }^{82}$ From this 'received' point of view, that is to say, from what the 1960s counterculture once called the 'establishment' perspective, approaches like Nietzsche's or like Husserl's or like Heidegger's philosophy of science are found lacking when they are acknowledged at all.

The upshot of this, in addition to the obscurity that follows from a tradition of deliberate non-advertence or blindness, is a certain intellectual anxiety on the part of those who write about continental thinkers in the context of philosophy of science. Hence and although Husserl is the ideal crossover philosopher between analytic and continental philosophy, two recent (and respectably mainstream) commentators, Richard Tieszen and Thomas Ryckman begin their differently rigorous accounts of Husserl's relation to the philosophy of science and philosophy of mathematics by adverting to a tradition of derision. ${ }^{83}$ As Tieszen complains, Husserl's views on mathematics have 'been subjected over the years to extreme discussion, criticism, and even ridicule' (Tieszen 2005, 69). But in a parallel spirit, Ryckman emphasizes that one can have no access to Einstein's theory of relativity understood together with Weyl's theory of relativity (a complex point only expanded by referring to Poincaré), unless one adverts to its intrinsic expression in a language entirely alien to those interested in philosophical issues in mathematics and physics [namely] the language of transcendental phenomenological idealism of Edmund Husserl' (Ryckman 2005, 7; cf. 109). ${ }^{84}$ Such authors fear that their research may be discounted in advance as it sometimes is.

The same anxious worry may be said for those who write on Heidegger and science/ mathematics/logic. Heidegger is even less amenable to mainstream appropriations in the philosophy of science in spite of the stalwart and commendably analytic efforts of Joseph Rouse and others. This tradition of opposition or dis-attention or exclusion in Anglophone scholarship can be dated to William J. Richardson's article on Heidegger's philosophy of science, ${ }^{85}$ and although this resistant tendency continues, it has also been ameliorated by Patrick Heelan along with Patricia Glazebrook's work along with Daniel Dahlstrom's magisterial study (published in both German and English) of Heidegger's Theory of Truth in addition to the analytically minded but still hermeneutically sensitive Dimitri Ginev and the yet more mainstream Michael Roubach. ${ }^{86}$

Within analytic philosophy the practice of exclusion is effected with the rhetorical force characteristic of the analytic tradition of philosophy, as analytic philosophy, in its tradition, seems to specialize in ad hominem attacks. ${ }^{87}$ Thus in the early part of the twentieth century, Henri Bergson, who had initially been widely celebrated not only on the European continent but in England and the Americas, came to be the victim of just such rhetorically savage criticism (while and to note another and counter-intuitive 
parallel, Bachelard was not so vilified, just as Canguilhem and Serres are similarly read with approbation).

Although and as Tiezsen and Ryckman separately attest, Husserl's thought has been subject to aggression, Husserl is increasingly of interest to both analytic and continental philosophers of science. By contrast and as much as Nietzsche, almost but not quite as much as Bergson, Heidegger's philosophical thinking on logic, knowledge, and science but also technology has been rejected out of hand, which means without serious engagement, notoriously in the case of logical epistemology, drawing the criticism of Carnap and Ryle in addition to Popper and many others.

Within mainstream philosophy of science alternative approaches such as continental philosophies of science have thus been silenced and, if one may be permitted to use the 1919 language of the utterly non-analytic and obsessively and anecdotally empirically inclined Bronx archivalist of science, Charles Hoy Fort (1874-1932), 'damned' in this fashion (Fort 1919). Fort loved facts as they were observed and chronicled or reported. At the same time he observed that some reports would be taken up and repeated and, by being so repeated, 'verified' (to use Popper's terms) in a constatation of reception, while other reports managed, like so many mayflies of the dailies, to vanish after only a single notice. Fort's Book of the Damned is a painstakingly articulated tissue of such 'endangered' newspaper and journal reports. The point of 'damnation' ensures that reference to certain observations as observations are excluded in advance as is reference to certain 'facts' as facts, thus such observations and facts (along with any mention of them) are banished from scientific discourse, 'damned' by nothing more arduous than mere non-citation.

Fort's image of the 'damned' corresponds to the scholarly excommunication characteristic of both the modern scientific and journalistic (and we can add: philosophical) establishments. ${ }^{88}$ Thus we can think here of Pons and Fleischmann's precipitous announcement of their work on cold fusion ${ }^{89}$ and of Peter Duesberg's research on the viral etiology of AIDS as well as the controversy on vaccination for both children and pets, and always and again, the controversies on cancer and its causes. ${ }^{90}$ Political and social reflections of such scholarly and 'scientific' silencing continue to have implications for the history of biological research, not to mention the intersection of science and politics, and contemporary accounts (especially of the economics) of science are beginning, gingerly, to take up the complex challenge of such discussions.

\subsection{Philosophy of Chemistry: Synthesis and Neglect}

Chemistry would seem to be the most physics-like of the non-physics natural sciences, but recent work in the philosophy of chemistry has underlined the dangers of the reductionist tradition of representing chemistry on the model of physics (cf. Scerri 2000 and 2005). But where Fritz Paneth ${ }^{91}$ sought to make these points from the perspective of the philosophy of chemistry in the 1930s, the response, as Jaap van Brakel (1999) details, has been either utterly lacking or glacially slow in mainstream philosophy of science. ${ }^{92}$ Indeed, as one scholar argues, the 'one-sided picture of science tailored to physics' (Schummer 2003, 37) has often meant that analytic philosophers of 
science are unaware of the philosophy of chemistry rather in the way they are generally unaware of the philosophy of biology or economics in spite of the important work of theorists like von Hayek and Michael Polanyi. ${ }^{93}$ Duhem, himself a physical chemist, similarly emphasized the exceptionality of chemistry, pointing to Kant's observation that 'the theory of bodies can only become a science of nature when mathematics is applied to it' (Duhem 2003, 31).

For his part, Fritz Paneth refuses the reduction of chemistry to physics for the critical phenomenological reason that the aim of physics is ultimately to reduce 'sensory qualities to quantitative determinations' (Paneth 2003, 16). Like Duhem, Paneth invokes Kant's mathematical conventionality as justifying the exclusion of chemistry as a science, arguing that to the extent that 'chemistry is essentially non-mathematical' (ibid., 118), ${ }^{94}$ it was the analytic research chemist, 'unhampered by mathematics or indeed almost any theory, who discovered the majority of all chemical elements on the basis of the most primitive concept of substance!' (ibid.). The effectively unchanged basis of chemistry, i.e., the basic schema of the periodic table associated with Medeleev (but see Scerri 2006), offers a corroboration of this point as Paneth underscores it, referring to the periodical order 'already in the seventies of the last century, the elements had been arranged by the chemists into a scheme, the so-called "natural system of the elements"' (Paneth 2003, 118), a system importantly unchanged in its character despite the innovations of twentieth-century atomic theory.

Speaking here of substance as either basic (non-observable, theoretical, or in some philosophic expressions, constructed) or simple (observable), Paneth undertakes to explain the notion of an element: 'the whole body of chemical theory lies in the assumption that the substances which produce the phenomenon of 'simple substances' serve in the quality-less, objectively real sphere of nature as "basic substances"' (ibid., 130). Rather than progressing towards a more mathematized chemical science on the model of physics, one would do well to return to the philosophical origins of the concept of the 'elemental' (and Paneth means such a return in earnest as he invokes the Epicurean notion of 'mixing') in order to avoid equivocation when speaking of either the permanence of substance or the chemical/alchemical achievement that is the 'creation of a new substance by mixing two known ones' (ibid., 123). ${ }^{95}$

As the 'science of the transformation of substances' (van Brakel 1997), in other words, chemical synthesis generates new compounds and what we understand by 'substance' (here regarded as much philosophically as scientifically) matters for a phenomenological understanding of such new compounds. If Paneth refers to Karl Joel's 1906 allusion to the 'genesis of nature philosophy in the spirit of mysticism' (Paneth 203, 24), we do well to note that 'the challenge posed by chemistry is that its irrationals are incorporated in matter: they are everywhere, in a glass of sugared water or in the kitchen salt that we use every day' (Bensaud-Vincent 2005, 646). ${ }^{96}$

\subsection{Philosophies of Geology or Modelling and its Discontents}

No less than the developments in physics in the period that concluded the nineteenth and began the twentieth century, geology has perhaps had the most diverse range of 
influences, as we have already pointed to the influence of the Italian geologist and historian of cartography, Uzielli, who wrote influentially for Pierre Duhem on Leonardo. ${ }^{97}$ And an 1846 account of the origins of geology as a science can be found in Jobert's Philosophy of Geology. ${ }^{98}$

The changes in geology arguably inaugurated the greatest conceptual shift in postNewtonian science, noting the upshot of the challenges of William Thomson (Lord Kelvin) to the Hytton-Lyell 'uniformitarian' theory of geology ${ }^{99}$ in the 1860 s. As the name suggests, the uniformitarian theory of geology assumes the constancy of the earth's relative position in the solar system and the stability of the geological features of the earth itself over long periods of time. Although his challenge to uniformitarian theories of the age of the earth was well-founded and has since been born out in the main, ${ }^{100}$ as a model, Lord Kelvin's own particular and 'elegant' (or simple) mathematical model failed to model the very complex dynamics of the earth's geological evolution (and indeed its present) and hence his estimate of the age of the earth, for all its mathematical 'correctness' was nonetheless inaccurate. If Kelvin's model was rejected, it is worth noting that accepted models are surprisingly proof against revision or correction and can even continue to be applied in the absence of empirical viability. Thus and in a context attuned to both geology and mathematical modelling, Orrin Pilkey and Linda Pilkey Jarvis raise the question of the use of models in theoretical and applied science (Pilkey and Jarvis 2007, 27ff.). Pilkey and Jarvis point out that in practice and in textbooks as in handbooks (and their revisions), models are assumed and routinely declared to be but are often not modified in fact, a happenstance one would think grievous in any applied science.

From a theoretical perspective, it was Kelvin's model and its associated mathematical frame of thought that led to the Second Law of Thermodynamics as expressed in 1865 by Rudolf Clausius, culminating in what may be the most profoundly philosophical scientific notion, that of entropy, and its correspondent vision of the heat death of the universe. It is this that inspired Poincaré's recurrence theorem (articulated during 1889-97), which argued, much as Nietzsche's theory of the eternal recurrence of the same (both very patently in response to the Kelvin), that in a closed or bounded system, all events return, infinitely many times, to their initial state. ${ }^{101}$

An instantiation of theory change (and a dramatization of its vicissitudes in terms of the establishment resistance to the same) may be seen in Alfred Wegener's initially ridiculed 1912 theory of continental drift. Even when the present author was a science student at SUNY Stony Brook in the 1970s her teachers (some, not all of them) mocked the theory and it has only relatively recently come to be accepted. ${ }^{102}$

Geology has been influential in biology, especially via the same Charles Darwin ${ }^{103}$ who pointed out that it might be useful to follow the model of language filiations as noted at the start, and it is geology, precisely unprepossessing as it can seem, that can be argued to have inaugurated the current attention to the gentlemanly and modest witnessing turn in the history of science. ${ }^{104}$ For a host of reasons-theoretical, contextual-hermeneutic, but also with respect to the history of the atom bomb and its development, including the interest in detecting covert testing during the cold war ${ }^{105}$ - geology remains significant in continental expressions of the philosophy of 
science. ${ }^{106}$ The philosophy of geology, much like the philosophy of chemistry, has been slow to receive attention, if recent work suggests that this is beginning to change (Harré 2000). Thus it is that the philosophical fortunes of related sciences like geology, like geography, ${ }^{107}$ but also like economics and chemistry, as well as biology, can all be said to mirror the fortunes of continental philosophy of science not least because analytic philosophy of science has tended to be silent on such sciences.

\subsection{Biology or Cell Wars and Crying 'Fraud': The Case of Haeckel, Moewus, and Mendel}

Science is often, although quite erroneously, taken to be a discipline that proceeds independently of political and economic forces. The most well-known articulation of the politics of science in this temporal context, named after Paul Forman and his studies of the influence of Weimar culture on quantum theory, ${ }^{108}$ has since been applied with certain limitations to other time periods and loci as well. ${ }^{109}$ But the thesis Forman develops is in turn founded upon another well-known approach to the history of science, namely from Butterfield's 1931 The Whig Interpretation of History which, as already noted, is often invoked eponymously for a certain approach to the history of science. ${ }^{110}$

Here, with reference to biology it is worth noting that an historical awareness of social influences is often attenuated by a reductionist tendency deriving from the philosophy-of-sciences emphasis on physics, as articulated in Ludwik Fleck's challenge to the very idea of demarcation as such in his famously provocative Genesis and Development of a Scientific Fact. ${ }^{111}$ This reductionist emphasis drives the ultimate formation or disciplinary demarcation of a scientific field. Thus the biological sciences saw a highly successful transformation of a nineteenth-century scientific field on the terms of physics and chemistry, to take the example of molecular biology at the start of the last century. ${ }^{112}$

If Loren Eisley could, with a good deal of historical justification, speak of Darwin's Century, arguing that in a scintillatingly metonymic crystallization, Darwin's name came to stand in the place of (and thus to elide) a range of researchers and their traditions, disciplines, ideas, etc. (Eiseley 1961), Ernst Haeckel can be regarded as an exemplification of this cult of individual celebrity who while retaining his own distinct profile was also the object of calumny.

Called the 'German Darwin' as an enthusiastic advocate on behalf of the original Darwin, Haeckel was a specialist on unicellular and colonial protists (or eukaryotic microorganisms), as well as sponges and worms and he is especially noted as one of the first to speak of ecology in the modern sense. In addition to other exponents of biological theory in the nineteenth century, such as Wilhelm Roux and others, Haeckel had an important influence on Nietzsche's perspectival and eco-physiological philosophy of science. ${ }^{113}$

Yet, merely by invoking Haeckel's name one also generates a host of ideological associations, a point essential to untangle especially in its connection with Nietzsche, especially given contemporary readings of Nietzsche and biology as well as Nietzsche and Darwinism. A discussion of the German origins of Darwin's thought incites, if possible, 
still more controversy, ${ }^{114}$ thus I limit myself here to the discussion of the role of society and other influences on the reputation of a scientist and the shaping of a discipline using the example of Haeckel and, secondly and as a specifically 'textbook' case of science fraud: Franz Moewus, just because of the scholarly reputations and consequently the level of energy spent on both, where especially the latter turns out to be much the worse for wear.

Haeckel, a student, among other influences in his life, of the cytological pathologist Rudolf Virchow, had adapted some of Virchow's political metaphors for his own study of multicellular organisms, ${ }^{115}$ importantly linking morphology with Darwin's evolutionary theory (Haeckel 1866). Haeckel's 1889 expression of the 'battle for existence' (Kampf ums Dasein) (Haeckel 1998), borrowed as it is from the title of Bronn's translation of Darwin's Origin of Species, recalls the Darwinian ideal of the survival of the 'fittest', invoking Thomas Malthus's Essay on the Principle of Population as Darwin attests in his own introduction to The Origin of Species. ${ }^{116}$ This Malthusian/Darwinian association was a mainstay of turn-of-the-century readings of Nietzsche and its influence has not abated to the present day. ${ }^{117}$ This same agonistic dimension together with Haeckel's emphasis on the division of labour (more than a matter of struggle or conflict) may be found in Nietzsche's notebooks (Nietzsche 1980, vol. 7, 143, 477 and vol. 10, 332). Indeed, Nietzsche reprises Haeckel's arguments against war in a section of Human, All-too Human (Nietzsche 1980, vol. 2, 314-261), echoing Roux, the founder of experimental embryology, in the process. ${ }^{118}$

Haeckel's precisely stylized and aesthetically beautiful illustrations, especially those in his Artforms of Nature (published during the years 1899-1904), continue to inspire students of art and biology. ${ }^{119}$ But even on the level of these images, Haeckel's influence is not unmixed, perhaps because Haeckel's illustrations cannot but be seen and judged in contrast with the now-standard depictions of a new century of photomicrographs and other imaging techniques. ${ }^{120}$ Our contemporary scientific world view is one that favours and can only favour fixed or prepared specimens_-stained bacteria are dead or preserved, fixed bacteria. Any subject for electron microscopy is a prepared artifact of the imaging technique in the strongest possible sense of the word. But Haeckel examined his subjects with the experimental techniques (in the field, not merely to collect his specimens but to draw them) and with the sensibility and artistic eye of another era. Thus for us today, Haeckel has been, to use Charles Fort's terminology, scientifically 'damned'.

Because Haeckel drew what scientists using new technologies increasingly decided could not be 'seen' otherwise than by using their own imaging techniques (and thereby producing the kind of images recognizable as such), Haeckel in the new century, would be charged with nothing less than 'fraud'. ${ }^{121}$ Far more egregiously, the same charge, for much the same reasons, ceteris paribus, indeed, would be levelled against Franz Moewus, the phycologist who developed the 1919 work of his teacher Hans Kniep on the sexuality of algae (see G. Smith 1946 as well as Sapp 1990 and 2003, Harris 2001 and Davis 2003). The basis for the charges of 'fraud' in both cases of Haeckel and Moewus include political elements as well as aspects of hermeneutic dissonance. What is at stake in the charge of fraud also concerns the fate of scientific 'discoveries' or observations 
that either go against the received or official account—we should think here again of cold fusion or even homeopathy or acupuncture ${ }^{122}$ - or, as in the case of Moewus, may simply be sufficiently subtle or delicate enough to be difficult to replicate.

For if aesthetic concerns are involved in Haeckel's case, the problem in Moewus's case was that his research results were 'too good' to be true. If Moewus had some defenders at the start (and in those who remembered him in their own lifetimes), it would transpire that he would lose utterly, as Jan Sapp's (1990) study further cements this loss for today's reader. It is an ironic testimony to his disputed researcher's skills, that these same technical abilities would assure him employment as a lab tech at the end of his life after he had lost his reputation, along with his academic rank and researcher's salary.

The assumption is that any scientist can or should be able to do what another has done and when it comes to algae culture, so it has indeed been argued, this is not so. As Trevor Pinch reminds us, no account of the test circumstances as we can consider them allowed Moewus much time (or grace). This awkward (and that is the very nature of this kind of suspicion) state of affairs means that one can take the charges of non-reproducibility on faith, just as, in other cases, and in biological scientific practice, one takes reproducibility on faith. ${ }^{123}$ Everything would thus appear, as in other more routinely political forms of life, to turn on the researcher's reputation. Results that are difficult to replicate can be dismissed as fraudulent (and what else would/can one do?).

Justified or not, disproving allegations of fraud is harder in the scientific world than suggesting it in the first place, such charges can end a scientist's life. Instructively (and paradoxically) the rightness or wrongness of Moewus's discoveries regarding the cytological basis of inheritance are irrelevant and if Moewus's research has been subsequently confirmed in its general lines no discussion of the topic mentions or would mention his name (even if the conclusions drawn repeat his conclusions).

Molecular biology can appear to have more than its share of challenges of data falsification and the inherent difficulty of replicating experiments across disparate scientific cultures of cell culture and chemical techniques. In Haeckel's case, the problem was further exacerbated by a book-printing culture constrained not least for economic reasons to save on the reproduction of colour plates but not less by a scientific and reflective tradition of patterned and associative arrays dating back to Kepler and before. Like Ernst Chladni's systematic representation of the sound patterns first attested to in modern times by Galileo and which so intrigued Nietzsche, ${ }^{124}$ Haeckel rarely used just one illustration but favoured stylized, constellations of multiple illustrations on each individual plate. ${ }^{125}$ The issue of accurate sketches was subsequently rendered irrelevant with the establishment of photography in place of illustration. ${ }^{126}$ Ironically, a growing consciousness of and familiarity with the distortions of photography and with digital enhancements of scientific images, has begun to suggest to some interpreters that the question of artifacts and interpretive liberties may be due for a renewed thematization.

\section{Concluding Note on Being, Science, and Time: On Husserl, Gödel, and Heidegger}

In philosophy of science in general, continental and otherwise, it is impossible to overstate the importance of Hilbert's 1900 program to set mathematics on the 'completed' 
path of a science, expressed as Hilbert's 'conviction', as Hilbert described it: a 'conviction (which every mathematician shares, but which no one has as yet supported by a proof) that every definite mathematical problem must necessarily be susceptible of an exact settlement' (Hilbert 1902, 444). Famously, as we know, Hilbert's programmatic conviction would be proven un-provable 30 years later by a young mathematician who began his work as a mathematician by following out the very course specified by Hilbert's 1900 programme. $^{127}$ As the very title of the (1962 edition of the) English translation of Gödel's 1931 first incompleteness theorem already indicates, Gödel was able to prove that all consistent formulations of such formal systems as number theory include undecidable statements (Unentscheidbare Sätze) (see Gödel 1962). Beyond this, the second incompleteness theorem states that the consistency of arithmetic cannot be proved in arithmetic itself or on its own terms, using the methods of first-order predicate calculus. As Jean Cavaillès has articulated Gödel's second theorem, 'noncontradiction of a theory can be demonstrated only within a more powerful theory' (Cavaillès 1970, 406; my emphasis). But this means that consistency can only be proven if the formal system is augmented-or 'completed'.

In his discussion of Gödel's theorem, the Belgian philosopher of science and mathematics, Jean Ladrière, noted that the distinction between mathematics and metamathematics can only be resolved hermeneutically: 'It is possible to interpret a certain part of the formalism under study either as part of arithmetic or as its own metatheory' (Ladrière 1970, 469-470). Using Husserlian language, Ladrière also emphasizes that this is the precisely phenomenological issue of application or relevance. 'Mathematics is neither a physics nor a poetics. It is the act which constitutes an autonomous reality in the very movement in which it explores it' (ibid., 478).

Gödel's incompleteness theorem as first expressed in his essay on the undecidability of propositions touches exactly upon Hilbert's ideal of axiomatic consummation. Like Cavaillès, most commentators note that one needs a higher order or more powerful system in order to prove consistency but the problem remains as this too undermines the foundationalist ideal of a complete axiomatic system. ${ }^{128}$

There is no little tension in the literature regarding Gödel's philosophical accomplishments in the field of logic and many scholars claim that it is easy to overstate the consequences of Gödel's incompleteness theorems, ${ }^{129}$ patent enough, as Gödel's theorems are all about formal restraint. As Cavaillès ${ }^{130}$ reminds us, the 'result of Gödel's work is well-known: every theory containing the arithmetic of whole numbers, is necessarily non-saturated. A proposition can be asserted within them which is neither the consequence of the axioms nor in contradiction with them' (Cavaillès 1970, 405) or, said in other words: no formal system can be both consistent and complete. That literally formulaic incompleteness is the reason Gödel's incompleteness theorems cannot be gotten round despite the all-too human and particular detail that ordinary formalization projects continue today in mathematics, with appropriate 'work-arounds', as ever they did.

Analyzing the geometrical foundations of mathematics, Richard J. Trudeau quotes Ernest Nagel and James Newman as arguing that it is impossible to establish the logical consistency of any complex deductive system except by assuming principles of 
reasoning whose own internal consistency is as open to question as that of the system itself (Trudeau 2001, 246). Thus Bachelard, whose interest in technique we noted at the start, cites Cavaillès as emphasizing with regard to Gödel that 'the reference to technique is a subterfuge', going on to declare that here: 'technique takes its revenge by subverting the constructions realized in an abstract realm that surpasses it' (Bachelard 1970, 354).

Beyond his work in mathematical logic, Gödel's ambitions were philosophical, as Gödel wrote to the phenomenologically oriented mathematician/philosopher, GianCarlo Rota (1932-1999), 'Transcendental philosophy ... carried through, would be nothing more nor less than Kant's critique of pure reason transformed into an exact science' (in Yourgrau 2005, 107). In particular, Gödel's interest in time was expressed in the same Kantian spirit, as Gödel believed, in Yourgrau's paraphrase, that 'the attempt to discover what is fundamental about our thinking about time can receive no assistance from physics which, he argued, combines concepts without analyzing them' (ibid.; cf. Heidegger 1985). We have instead to 'reconstruct the original nature of our thinking' (Yourgrau 2005, 170).

It is regrettable if unremarkable given the differences between Anglo-American and continental styles of philosophizing that throughout his life Gödel himself would be excluded from mainstream debate on the philosophical reflections on the problems of physics and mathematical logic, and especially the philosophy of time. Yourgrau outlines one such example in detail: Gödel's contribution to Schilpp (Gödel 1949) was judged mistaken, a judgment seemingly made 'on principle' according to Yourgrau who argues that the presumption of error was not the result of but much rather made in the absence of debate (Yourgrau 2005, 119-120). Even in the long course of the more than half-century of scholarship to follow, Yourgrau observes 'Gödel's contribution to the Schilpp volume had almost no impact on the community of philosophers' (ibid., 120). In effect, Gödel was judged to lack the credentials needed to theorize as a philosopher (ibid., 121).

The phenomenon as we already noted at the start is the all-too-political, academic tendency to refuse what is not expressed in the style of (and that also means, and here a parallel with science, natural and social may also be made: failing to cite the dominant names of) the 'profession'. (What else do 'peer' reviewers look for in order to certify the 'quality' of given contribution?) In other words, shades of continental philosophy of science in general, Gödel failed to employ the writing style of analytic philosophy, failing in addition to refer to the 'right' names in American analytic philosophy in his own contributions to philosophy. ${ }^{131}$ For Yourgrau, Gödel was a philosophical outsider, even given his position at Princeton, even given his extraordinary fame. Gödel indeed

had never been a member of the club, he was out of touch and out of step with the philosophical establishment. ...To many philosophers it must have seemed as if Gödel had slept through not one but two Wittgensteinian revolutions. It added insult to injury that W. V. O. Quine, the dominant figure for years in American philosophy and the most analytic of analytic philosophers, was also absent from Gödel's thinking. (Yourgrau 2005, 121) 
The debate concerning axiomatic systems and the reflexive limitations of formal systems, ${ }^{132}$ debates originating with Hilbert's Göttingen and Cantor's Halle, are debates that must be set in the particular historical context that is ultimately indispensable for a philosophic understanding of both Gödel and Einstein. This debate has everything to do with the historical and hermeneutic context of the time, that is also to say as Heidegger and Nietzsche would emphasize, the interpretive terms of the debate in question turn upon the language of the debates, that is: the terms used, that is: again, the theoretical framework. We have seen that many accounts (Heelan, Tieszen, Ryckman as well as Hill and others) emphasize the crucial geographical importance of these same genial locations for Husserl's world view.

If Gödel himself refers to Husserl, mainstream scholars continue to overlook references such as these, at times invoking Frege's supposed demolition of the project of phenomenology as decisive. The blinders of the calculatedly academic predispositions noted at the start are dangerous inasmuch as they block an appreciation of the significance of continental philosophy of science in its broadest intellectual and cultural context but they also block the reception of Gödel's contributions to the questions of time, such that rather than engage or criticize Gödel, analytic philosophy has been inclined to follow Hilary Putnam when he writes: 'I do not believe that there are any longer any philosophical problems about Time; there is only the physical problem of determining the exact physical geometry of the four dimensional continuum we inhabit' (Putnam, cited in Yourgrau 2005, 111).

Beyond the very real and very ongoing philosophical problem of time, ${ }^{133}$ prejudices against the language and emphases of 'continental' thinkers on science create needless obscurities in a field that is already nuanced and complicated, mere artefacts of calculated inadvertence: why, we should be able to begin to ask, did Hausdorff and Čapek read Nietzsche on issues of logic and cosmology and indeed time? What is Nietzsche's philosophic thinking on such topics as on science itself and as such? What was the resonance between Husserl and Cantor or as Ryckman shows with such exhaustive care, or Husserl and Carnap, as Cavaillès empasizes this, or Husserl and Weyl or as Tiezsen and Yourgrau and Rota show, between Husserl and Gödel? How shall we understand the relation between Poincaré and Einstein and how might we add Husserl? How is Heelan able to read this mathematical world view into the importance of Husserl for Heisenberg and the importance of both for the still excluded name of the Canadian philosopher, Bernard Lonergan? And what indeed would have been the basis for the friendship between Heidegger and Heisenberg or else Heidegger and Ludwig Binswanger or Heidegger and Jacques Lacan?

Such questions would be less esoteric and less recalcitrant if mainstream thinking on science and philosophy did not continue to perpetuate the conditions of the analyticcontinental divide even where this divide is declared resolved as it continues to exclude voices and refuses engagement with contemporary continental philosophers of science. In this sense the still ongoing terms of the analytic-continental divide are the mainstream terms of those for whom there is no divide at all, excluding a world of detail, a generation of scholars, and a wide range of historically contextual reflection. It is no wonder that Heidegger could call for thinking or that Gadamer could remind us that 
we need to learn how to invite others not simply to listen in but also to have a share in the conversation of philosophy.

\section{Notes}

[1] In the same way, what is called a continental breakfast can be served at any hotel in the world. Jean Grondin 2000 takes this example, not without some chagrin, as point de départ for his hermeneutic analysis of what he calls the 'tragedy' of understanding (and mis-understanding) in professional philosophy. See too Boundas 2007.

[2] In addition to Preston 2007, Soames 2003, and Hacker 2006, see Giere and Richardson 1996 and Friedman 1999 as well as Friedman 2000. See too Cahan 2003, Daston and Galison 2007, and yet more intriguingly, Hands 2005.

[3] In a section entitled "The Scandal of "Continental Philosophy" in a recent essay on the "nonexistence' of Polish philosophy, Barry Smith details the complaint that what is called continental philosophy in North American universities is 'centred above all around the person of Martin Heidegger' (B. Smith 2006, 19), a sentiment also expressed contra Derrida, though Smith for his part would presumably be happy to include Deleuze, Nancy, and indeed any other 'currently fashionable' French thinker.

[4] See Mulligan 1998 as well Mulligan 1991 as well as the other contributions to the 1991 issue of Topoi: Continental Philosophy Analysed.

[5] See for a discussion of the difference this makes Babich 2003a and 2007a.

[6] Adorno and Horkheimer 2002 analyze this phenomenon, but see also Nietzsche's discussion of Ressentiment in Nietzsche 1980, vol. 5, $270 \mathrm{ff}$.

[7] In using this plural characterization, I follow Rom Harré's usage in Harré 1989 [1972].

[8] See Feyerabend 1984 as well as Haller 1982. See too Wolters 1987 and 1989 as well as Banks 2003 and 2004 in addition to Brush 1968. See, too, the contributions to the collection edited by Cohen and Seeger 1970 and R. Cohen 1968 as well as, more broadly, Stöltzner 1999. On Becker, see the contributions to Gethmann-Siefert and Mittelstrass 2002, and in relationship to Heidegger and Nietzsche, see Giugliano 2005.

[9] See Babich 1994. On Mach and Nietzsche, see Wright 1993, 55-56, and, similarly articulated via a reading of Musil, Pieper 2002. For a sketch of Nietzsche's interaction with Mach (and Avenarius), see Brobjer 2008 in addition to Stack 2005 on Nietzsche and Mach with specific reference to the 'economy of thought'. And in today's tradition of source scholarship, see Gori 2009.

[10] I have to say 'only slowly' although the present author has been writing about this for going on a quarter of a century because that work has been as little engaged or as deadborn as anything Hume ever wrote. In addition to Babich 1994, forthcoming in an updated edition as Babich 2010a, see also 2010b. But see too the other contributions to Gentili and Nielsen 2010 as well as Babich 2010c. A selection of those who have written on Nietzsche and science include Milič Čapek, Rüdiger Grimm, Hans Seigfried, Reinhard Löw, Robin Small, Alwin Mittasch, Alistair Moles, Klaus Spiekermann, Walter Zimmerli, and indeed and in connection with Nietzsche's critique of logic, Martin Heidegger. See also the contributions to Babich and Cohen 1999a and 1999b as well as Brobjer and Moore 2004. Intriguingly, July 2010 saw an extended international conference at the Technical University of Berlin dedicated to the topic of Nietzsche's Philosophy of Science/Nietzsches Wissenschaftsphilosophie with Nietzsche scholars as well as traditional philosophers of science. It makes a great hermeneutical difference to read Nietzsche's thinking on science in German rather than in translation as the current author can now attest (Babich 2010a, 396).

[11] See for an explication of this concern in an explicitly epistemological context Babich 2010c.

[12] Thus analytically minded as it is, Gutting's 2005 collection fails to include Nietzsche. Yet even continentally oriented Nietzsche experts can fail to note Nietzsche's own thinking or advert to 
secondary work on Nietzsche's philosophy of science, even in overviews dedicated to representing the scope of Nietzsche scholarship. See note 10 above for exceptions.

[13] Gerald Holton 1978 invokes Nietzsche alluding to Albert Szent-Gyorgyi's own comparison of himself and Einstein, to distinguish between Apollonian and Dionysian tendencies in history and philosophy of science.

[14] I make this claim in Babich 1994, and develop it more explicitly elsewhere, most recently in 2010a, 2007b and 2010c.

[15] As we read in Nietzsche's inaugural lecture: 'The entire scientific and artistic movement of this peculiar centaur [i.e., philology qua science] is utterly dedicated, though with cyclopic slowness, to bridging the gulf between ideal antiquity — which is perhaps merely the most beautiful flowering of the Germanic passion for the south — and real antiquity; and therefore classical philology strives after nothing but the ultimate consummation of its own essence, the complete fusing together and unifying of initially hostile impulses that have only been brought together with force [Die gesamte wissenschaftlich-künstlerische Bewegung dieses sonderbaren Centauren geht mit ungeheurer Wucht, aber cyklopischer Langsamkeit darauf aus, jene Kluft zwischen dem idealen Altertum-das vielleicht nur die schönste Blüthe germanischer Liebessehnsucht nach dem Süden ist—und dem realen zu überbrücken; und damit erstrebt die klassische Philologie nichts als die endliche Vollendung ihres eigensten Wesens, völliges Verwachsen und Einswerden der anfänglich feindseligen und nur gewaltsam zusammengebrachten Grundtriebe]' (Nietzsche 1994, 289).

[16] 'Nachdem die geschichtliche Kritik sich mit voller Sicherheit der Methode bemächtigt hat, scheinbar konkrete Persönlichkeiten verdampfen zu lassen, ist es erlaubt, das erste Experiment als ein wichtiges Ereignis in der Geschichte der Wissenschaft zu bezeichnen, ganz abgesehen davon, ob es in diesem Falle gelungen ist' (Nietzsche 1994, 291).

[17] See for a discussion of this notion of method, the contributions to Schmied-Kowarzik 1995, especially Hoenigswald 1995.

[18] See on Lachmann, Timpanaro 2004 [1981], translated into English as Timpanaro 2006. Although Timpanero argues that Lachmann's method is based on Jacob Bernay's method, Nietzsche argues that the method is in fact much older. In addition to Nietzsche, see Glucker 1996. For a discussion of the role of Lachmann's method and the history of scientific classification, see Ginzburg 2004 and, on philology, stemmatics, and cladistics, Robins 2007, 90-91.

[19] Cf. Darwin 1867, 494. William Robins discusses this point, citing Darwin in Robins 2007, 90-91. Originally published in 1859, Darwin was first translated by the zoologist and paleontologist Heinrich G. Bronn in 1860 using the last years of life to do so, despite the fact that Darwin himself failed to acknowledge Bronn's own contributions. See for a discussion Gliboff 2008. The German reception of Darwin has been complicated and many-sided but the point about Bronn's contributions is that it was far from a one-way street. On language, Richards (2002) has reminded us that Darwin's conjectures owed much to his cousin, Hensleigh Wedgwood 1866, and also responded to Alexander (not Wilhelm) von Humboldt's remarks on language in the English translation of Humboldt's Kosmos which, Richards tells us, Darwin read in the 1850s. See further Richards 2008.

[20] Robins refers to J. Porter 2000 on Nietzsche and philology and Moore 2002 on Nietzsche and evolution. See also and again, Richards 2002 and on Nietzsche's science of philology and contributions to the same, Babich 2005.

[21] This 'scientific' style-orientation still dominates contemporary art history. See Alois Riegl's 1893 Stilfragen (translated into English as Riegl 1992) in addition to Riegl 2004 (see on Riegl here, Danto 2000). See too Max Dessoir 1927 along with Heinrich Wölfflin's evolutionary schema of stylistic development in his 1915 Kunstgeschichtliche Grundbegriffe (in English: Wöfflin 1932) among others who inaugurated the German tradition of Kunstwissenschaft, that is: the science of art. On Aby Warburg, see Woodfield 2001 and on Wölfflin, see Hart 1982. For a discipline-specific discussion of German-speaking approaches to art history, see Onians 1978. 
[22] Otto Jahn was also the teacher of Nietzsche's antagonist, Ulrich von Wilamowitz-Möllendorff as well as of Theodore Mommsen. Jahn combined an expert interest in both physical artifacts and contemporary music. For a discussion of Jahn and archaeology, see Donohue 2006, including further references, and see for a general overview, Müller 2009, 160ff. Even if it is evident that the dispute between Ritschl and Jahn was more collegial (or all-too-human) than substantive, it was in any case decided in favor of a kind of positive classicism, as already implied above, the still-ongoing philological legacy of Wilamowitz-Möllendorff.

[23] Otto Ribeck discusses this in two volumes (1878-81). See for further references and on scientific philology in general, Bontempelli 2004, here in particular, 210-211. See for a discussion of this notion of method in philology, the several contributions to Schmied-Kowarzik 1995. Note also in this connection, sheerly as a mention rather than a reference: the philologist Hans-Georg Gadamer's Truth and Method.

[24] Christian Benne observes that the relationship between Nietzsche and Ritschl deserves further engagement but he overlooks Jaspers while, however, taking care to note Andler's account as a result of what Benne calls contextualization or what one might also name hermeneutics (which to be sure Nietzsche himself would only call philology). See for this useful reference, Benne 2005, 46ff. See more broadly Brobjer 2007 and recall Robins's observation that the genealogical method of textual criticism, the epitome of scholarship then and now, 'depended on editorial judgment about which readings were 'errors' and which were not' (Robins 2007, 92). For his part, Robins depends on a limited range of Nietzsche commentary.

[25] Significantly both Nietzsche and his nemesis, Ulrich von Wilamöwitz Möllendorff would ultimately share this sentiment. See Benne $(2005,296 \mathrm{ff}$.) who offers claims for and against this position.

[26] See Duplouy 2006.

[27] See Miguel de Cervantes Saavedra, Don Quixote, pt 2, ch. 13.

[28] Also to be found in Hume 1965b. 'Of the Standard of Taste' was originally published in 1757 as the last of Hume's Four Dissertations. See for a discussion of the particularities of its publication, Mossner 1950. Most English translations observe that the leather in question is cordovan/cordoban.

[29] See for a discussion of Hume's essay, the late Patricia de Martelaere 1989, 125-126, MacLachlan 1986, and Friday 1998 among many others.

[30] For Nietzsche, the error, indeed the 'Mittelpunkt' of the errors in this context, is the precipitation of objective rather than subjective judgement on this same basis: see Nietzsche 1994, 299 and, again, 300 .

[31] See however Babich 2005.

[32] This notion far exceeds the current context and is far from a pat or settled question. But see, just to begin with, the three volumes of Crombie 1994.

[33] Nietzsche speaks of his 'Beängstigung und Scham'.

[34] Aber alles Leben ist Streit um Geschmack und Schmecken.

[35] See for example, Cooper 2010.

[36] See Venturelli and Richter 2003. I advert to the art historical context of this conception of style and its relevance for science apart from Nietzsche in Babich 2003b, see here, 76 and 81.

[37] See again Jaspers 1997, 176ff., and see, more broadly, Babich 2007b.

[38] See Babich 1994. See too the contributions to Babich and Cohen 1999a and 1999b.

[39] See in particular, my discussion of Alexandrian culture and science in Babich 2010a and 2007b.

[40] Avenarius 1888-89. See for a discussion, Arens 1988, 114ff.

[41] Although Thomas H. Brobjer calls for such an inquiry in Brobjer 2008, 94-95, and although Brobjer himself is a historian of ideas this author regrets that he contextualizes neither Avenarius' nor Mach's projects, which lack can lead to a presentist reading of Nietzsche. Brobjer's study is nonetheless invaluable as a contribution to source scholarship. The difficulty for me is highlighted by Umberto Eco's recent reading of the ongoing bugbear of relativity, as the lack of what 
Nietzsche called philology (or hermeneutics). Thus in his essay 'Relativism?', which first appeared in 2005 in L'Espresso, Eco on his way to identifying materialism and empirio-criticism as non-relativist, and the sole contenders for the distinction, includes Nietzsche amidst an incommensurable array of relativisms, noting however that 'Nietzschean relativism has little in common with the relativism of social anthropology because the former doesn't believe in facts and the latter takes them for granted' (Eco 2007, 310). I discuss Nietzsche and relativism, emphasizing the absolutism of the latter and advocating Nietzsche's perspectivalism (which I distinguish from perspectivism) in Babich 1994, 49ff., which I align with Alwin Mittasch's account that places this perspectivalism in the lineage of Leibniz and Kant.

[42] On Nietzsche and Weber, in addition to the authors named in the text, see Fleischmann 1964, Ansell-Pearson 1994, and Owen 1994.

[43] But see for a preliminary account, Solms-Laubach 2006. See Anstee 2006. Flyvbjerg 2007 regrettably condenses Nietzsche to Foucault. With reference to law, see Constable 1994. Simmel's reception of Nietzsche has recently received a certain amount of revived attention in economic theory. See Leck 2000. On Schumpeter, and Sombart, and Nietzsche, see Reinert and Reinert 2006.

[44] See on Nietzsche (in the context of a discussion of Wittgenstein and mathematics), Peters 2007.

[45] See for a discussion of Mittasch, Babich 1994, 65 and 74-75, and on the philosophy of chemistry in this connection including Mittasch, Babich 2010d, here 272-276. Martin Heidegger also read Nietzsche in connection with epistemology, science, and technology and Heidegger's friend, the physicist Carl Friedrich von Weizsäcker, who wrote of reading Nietzsche in his youth: see von Weizsäcker 1999.

[46] Although tracing its impetus back to the start of his career, Wigner's essay appeared only toward the end of his life: Wigner 1960. On Wigner, see Dijkgraaf 2008. Stack 2005, 210 refers to the conjunction between Nietzsche and Wigner (in the context of quantum mechanics and observability). Patrick Heelan, who worked with Wigner as well as Schrödinger, has also underlined the relevance of exploring the resonances between Nietzsche's thought and Wigner's paradoxical observation in personal conversation. See in general on consciousness and measurement, Heelan 2004.

[47] For a discussion, see Trudeau 2001. Andrea Nye raises a theoretical reflection on logic at the turn of the century in Nye 1990, 163-172, including a particular discussion of the 'force' metaphor inherent in such logical 'compulsion' in Frege's philosophy in connection with his own fascist allegiances. Irigaray's own reading depends upon a Lacanian discourse. See Irigaray 1985. For a discussion of Irigaray in the context of feminist epistemology, see Grosz 1994. More generally, see Schiebinger 1989 in addition to the contributions to feminist epistemology and philosophy of science in the work of scholars like Lorraine Code and Evelyn Fox Keller.

[48] Mongré 1897. See Scholz 2005 as well as Stegmaier 2002. See too, in the direction of a reflection on Nietzsche and empiricism, Epple 2006.

[49] See on the context common to both Poincaré and (only in passing) to Nietzsche as well, Brush 1978.

[50] Thus it is all too typical of authors to contend that the paradoxes of self-reference in logic and set-theory have no implications, affirming that anyone who draws out such implications has simply failed to understand the limitations of the same original context. Here it nearly goes without saying that Gödel himself would observe no such restrictions for his own part who hardly limited his incompleteness theorem to formal systems but took his own reasoning to bear on the formalizable or axiomatic system of physics itself and indeed, even beyond, if we are to trust the famous anecdote told about Gödel's 1947 citizenship hearings and his dialogue with his citizenship judge, one Philip Forman, who asked him, plausibly enough, if Gödel believed that a dictatorship like the Nazi regime that had so tragically taken hold in Germany could ever be possible in the United States. Gödel's reply was yes, on the basis of a formal 


\section{B. Babich}

inconsistency in the US constitution, an American dictatorship would have full constitutional blessings. Yourgrau 2005, 99ff.

[51] But, as if difficulties of translation were not enough, the historical referents to such scientific kinds as Nietzsche criticizes are of course not the same as those designated by the same terms today. See Small 2001 for a reading of Nietzsche and his contemporary scientific influences, including African Spir, Eugen Dühring, Gustav Teichmüller and Friedrich Lange, but also Ernst Haeckel, Richard Avenarius, and so on. The chemist Alwin Mittasch offers a sympathetic reading of Nietzsche's relationship to natural science in Mittasch 1942a, 1942b, 1944. For an extensive (but by no means exhaustive) philosophically oriented bibliography on the question of Nietzsche and science, see my research bibliography in Babich and Cohen 1999b, 341-358.

[52] There are a number of readings of this relationship. For a critical overview, see my discussion of Nietzsche and Darwin (Babich forthcoming) first presented as a lecture as the first amidst a year-long series of panels dedicated to Darwin in 2009-2010 at the Boston Center for the History and Philosophy of Science. I thank Fred Tauber for the initial invitation and for his friendly conversation as I also thank Bob Cohen for his friendship over many years. But I am also deeply grateful to Boston University's Center for the History and Philosophy of Science. I was a frequent and passionate visitor to the Boston University colloquia on the History and Philosophy of Science during my graduate school years in Boston and I am the kind of philosopher that I am because of it.

[53] In an exactly provocative rhyme against a number of views on Darwin, Nietzsche writes: 'An die deutschen Esel. Dieser braven Engeländer / Mittelmäßige Verständer / Nehmt ihr als 'Philosophie'? / Darwin neben Goethe setzen / Heißt: die Majestät verletzen—/ majestatem Genii! aller mittelmäßigen Geister // Erster—das sei ein Meister, / und vor ihm auf die Knie!/ Höher ihn herauf zu setzen / Heißt_—_-' (Nietzsche 1980, vol. 11, 318) and Nietzsche varies the accusation later on the same page.

[54] In an unpublished note entitled 'Anti-Darwin', Nietzsche writes: 'Was mich beim Überblick über die großen Schicksale des Menschen am meisten überrascht ist, immer das Gegentheil vor Augen zu sehen von dem, was heute Darwin mit seiner Schule sieht oder sehen will: die Selektion zu Gunsten der Stärkeren, Besser-Weggekommenen, den Fortschritt der Gattung. Gerade das Gegentheil greift sich mit Händen: das Durchstreichen der Glücksfälle, die Unnützlichkeit der höher gerathenen Typen, das unvermeidliche Herr-werden der mittleren, selbst der untermittleren Typen' (Nietzsche 1980, vol. 13, 313). For a representative 'pro-Darwinian' interpretation of Nietzsche's thought, see Podolsky and Tauber 1999. Note also Daniel Dennett's casual gloss invoking Nietzsche: 'Nietzsche's idea of a will to power is one of the stranger incarnations of sky hook hunger' (Dennett 1996, 466). Von Weizsäcker underscores Georg Picht's claim that Nietzsche's Darwinism was Lamarkian at best. See von Weizsäcker 1999, 223. See also Henke 1984 and Richardson 2004, etc. The present reader, by contrast, emphasizes Nietzsche's anti-Darwinism. See Babich 1994, 175-226, and forthcoming.

[55] But it is significant here to note Bruno Latour's seeming recantation (1999) of his prior reading of science studies. For a discussion of the relevant context, see Babich 2003b and 2002.

[56] See, especially for further references, Babich 1996, Crombie 1950 and 1994 in addition to Martin 1991, Stoffel 2002, and Schäfer 2006.

[57] Writing that 'all the scientific methods were already there' (Nietzsche 1980, vol. 6, 247), Nietzsche argues that the Greeks had already developed every 'prerequisite for a cultural tradition, for a uniform science; natural science, in concern with mathematics and mechanics, was on the best possible road-the sense for facts, the last-developed and most valuable of all the senses had its schools and its traditions already centuries old! Is this understood?' (ibid., 247-248). See too Babich 2010b. Cf. Nietzsche 1980, vol. 1, 804, 813 as well as vol. 8, 405, etc.

[58] On Greek science, see Charles Kahn on Anaximander along with newer scholars, such as Couprie, Hahn, and Naddaf 2003. See too Drachmann 1963 in addition to Oleson 2008 as well as Russo 2004. 
[59] Thus Feyerabend 1978, 59 repudiates 'the historical illiteracy of most contemporary philosophers and of their low standards of hero worship'. Feyerabend also notes that Popper only repeats Boltzmann, who 'often quoted Goethe's dictum that experience is only half experience $\ldots$ and then there is, of course, Mach's observation that already the name 'sensations' entails a one-sided theory' (Ibid.).

[60] See on this, among many others, Wallace 1990.

[61] With respect to Galileo, Feyerabend invokes Duhem by name (in express contrast to others, like Stillman Drake, who repeat Duhem's conclusion without mentioning his name), in order to argue that 'logic was on the side of ... Bellarmine ... not Galileo'. See Feyerabend 1989, 134.

[62] See H. Cohen 1994 and Boyer 1992. This critique to be sure is matched with a (rather less than influential) Catholic revival of his work: see the late Stanley L. Jaki 1988 and 1991 and, again, Martin 1991.

[63] This is also part of Feyerabend's argument in his 1989.

[64] I discuss this in Babich 2009b.

[65] A key example of the value of the secondary literature for Duhem's own scholarship was Uzielli 1894. Uzielli, who also wrote on Leonardo da Vinci and the cartographer Amerigo Vespucci, was a geologist and one of the founding members of the Italian Società Geografica in 1867. See Boime 1993 for a discussion of Uzielli's involvement with the theoretical, scientific, and artistic movments in Italy prior to and at the turn of the twentieth century.

[66] See too for its exemplification of the proximity to a different culture of historical scholarship, Thorndike 1941.

[67] See Veltman 2008 but see also Crombie 1970. Following Duhem, Crombie underlines the historical continuity between the work of Galileo, as well as Mersenne and Descartes, and thirteenth-century Oxford. In addition to Drake 1989 see Dear 1995 and 2001.

[68] See Yates 1991, Dobbs 1991 and 1975, and Principe 1998.

[69] But see for the relationship between alchemy and chemistry, the latter part of Paneth 2003. See Babich 2010d for a discussion with further references.

[70] See on the difference between history and philosophy of science, Wetterstein 1982. See too and again, Feyerabend 1978, 33ff., for an articulation of the contrast which is both wry and unparalleled. See further Hentschel 2003.

[71] Like bugbears, waterbears are bears only metaphorically. Waterbears, or tardigrades, are microscopically sized aquatic invertebrates, first discovered (and named 'kleiner Wasserbär') by the eighteenth-century zoologist and theologian, Johann Goeze. They are fascinating, even fun, but little understood to this day. I think it may help to imagine such bugbears on the model of tardigrades or waterbears: alien-seeming, fascinating, and intriguingly intractable as the only species we know that can survive nearly anything in a state of cryptobiosis. See, for fun (and for scientific illumination, biologically speaking): Mach 2009.

[72] See in addition to Jardine 2003, Alder 2002 as well as Cunningham 1988 and, to my reading, Vivanathan's plea for yet more historical and cultural sensitivity remains as yet still insufficiently received. See Visvanathan 1988 and 2006.

[73] Yourgrau $(2005,24)$ uses this expression to characterize the exclusion of Gödel from philosophy of physics. See too Jaki 2006.

[74] See for a conceptualization and overview with reference to both Planck and Schrödinger as well as others in the-then contemporary context, Stöltzner 2009.

[75] See Heelan 1965 and 1975. See too with reference to Heidegger, Hempel 1990.

[76] Heelan 1965 offers an initial and comprehensive elaboration including a study of perception and a specific context logic. Camilleri 2009 offers an overview of the intervening literature. More work remains to be done.

[77] Albeit without including the influences on Bachelard's work, names often forgotten today but essential to the philosophy of technology. Basso 1925 was influential, given its focus on the industrial arts and the relation between practical application and science, for Bachelard's dissertation, Essai de la connaissance approchée. Although the contextual reference to industry 
and science was essential for Bachelard and for later thinkers in the French tradition of the philosophy of science, there is no mention of Basso in Tiles 2005. See in addition, the section on Bachelard in Babich 1993.

[78] See for example, in addition to her contribution to Gutting, Tiles 1984 and Chimisso 2001 in addition to Gutting's earlier study. Indeed Bachelard's Marxist epistemology, where tolerated at all, is less and less received in departments of philosophy than it is in departments of geography along with the reception of Louis Althusser and Henri Lefebvre. On Althusser and Bachelard, see Jay 1986, $399 \mathrm{ff}$.

[79] See, in the biological sciences, Levins and Lewontin 1985 as well as Sheehan 1985 and Woods and Grant 2002 and on Engels in particular, Thomas 2008.

[80] See for further references, the works cited in the foregoing notes.

[81] This point can be difficult to explore because and in the same way that analytic philosophy in general increasingly appropriates continental themes, a recent and largely analytically minded collection, Gutting's Continental Philosophy of Science, omits not just some but the majority of contemporary continental philosophers like Joseph Bochenski, Azarya Polikarov as well as like Patrick A. Heelan, Joseph Kockelmans, Theodor Kisiel and Dmitri Ginev in addition to authors in the German tradition of constructivism (following Hugo Dingler) like Paul Lorenzen, Franz Wuketis, and Peter Janich, etc. Janich although usually quite neutral has recently complained of the Anglophone analytic tendency to completely disregard the German tradition of constructivism even where it contributes to debates in analytic philosophy. See the conclusion to Babich 2007a for a discussion of the extension of the same phenomenon of exclusion to critical Indian scholarship on the sciences which is often regarded as irrelevant to the philosophy of science per se from Ashis Nandy to Shiv Visvanathan. For further discussion, see Rajan 2005.

[82] The debate may seem puerile and contentious and that is the good reason that many scholars from Bob Cohen to Ruth Barcan Marcus (personal communication, in both cases), can be angered by such discussions, but one must speak truth to power, even as one seeks to be gentle with one's friends and very real and academic lives have depended on this very distinctive divide and many have suffered from it.

[83] See Ryckman 2005 and Tieszen 2005.

[84] Simons 2004 also offers an insightful reading of Husserl's own entanglement in the broader nineteenth-century context.

[85] W. Richardson 1968 refuses this appellation to Heidegger and then qualifies this refusal. See Seigfried's reply 1978 as well as Heelan 1995.

[86] See Glazebrook 2000 in addition to Dastur 2006 and others. Heidegger's interest in logic and mathematics is well known but it has taken a great deal to get scholars to take this seriously. But see for mainstream contributions Roubach 2008 as well as Käufer 2001 and Dahlstrom 2001 as well as Kisiel 1993 in addition to the contributions to Denker and Zaborowski 2006 in addition to earlier studies by Jean Ladrière and Wilhelm Szilasi as well and as more generally, Rainer Bast, etc.

[87] Speaking from a logical point of view, with an eye to the tenor of philosophical argumentation, informal fallacies - of course or else they would not function as such-largely have comparably informal justifications or fitting motivations, etc. See Hintikka 1987 and for an overview, pro and con, Boone 1999 and Wreen 1988.

[88] For his own part, Fort spent his life linking the politics and the practices of the two establishments. See for example, Fort 1919. For a contemporary discussion without Fort's prose, see the contemporary journalist, Greenberg 2001.

[89] It is important to note the continuing force of this chemical 'challenge' yet it is the distinction between physics and chemistry, and thereby the political order of rank between these two sciences that seems to have made all the political, theoretical difference for the scientific estimation and investigation of the first reports of cold fusion inasmuch as these reports were made by scientists who happened to be not physicists but chemists. Significantly, mainstream 
philosophy of science continues to regard cold fusion as an example either of pseudo-science or else as straightforward fraud. But see Biberian 2007 for an overview of the state of ongoing contemporary research.

[90] For criticism of the viral etiology of AIDS, see Bucchi 2004, 39ff., as well as, more broadly Proctor 1995, Harden 1992, Gallo 1991 and see especially Duesberg 1995 and Duesberg, Koehnlein, and Rasnick 2003.

[91] Paneth known for his work on isotopes, collaborated in 1921 on the use of radium D as a tracer with the Hungarian chemist George de Hevesy who later won the Nobel Prize in 1943 for this work. We have already cited several chemists, notably Bachelard but also Duhem and Berthelot. To these names, Bensaud-Vincent 2005, 634-665 adds Émile Meyerson and Hélène Metzger. For Bensaud-Vincent, the further considerations of feminist philosophy and history of science are essential because philosophers and historians of science tend to overlook otherwise significant scientific work owing to a double prejudice against women extending to those like Metzger who lack the 'prestigious diplomas' and to those even with diplomas who lack the crucial academic appointments that make all the difference for scholarly recognition (ibid., 644). The case of Mileva Marič or Marity, Albert Einstein's first wife and his mathematical and scientific collaborator, controversially listed as the co-author of his 1905 'Zur Elektrodynamik bewegter Körper', received by the journal, Annalen der Physik on 30 June 1905 signed Einstein-Marity, is a case in point. Inasmuch as the original manuscript in question has vanished, no resolution is possible, one way or the other, which does not stop historians from arguing otherwise.

[92] See further Liegener and Del Re 1987 as well as Scerri 2005 and van Brakel 2002. And see Dingle and Martin 1984.

[93] For a discussion of Von Hayek's and Polányi's philosophies of science, see Mirowski 2004.

[94] In a related but ultimately different point, some philosophers of science have argued that the difference between chemists and physicists can be found in the central role of the 'thought experiment' in physics just where it is conspicuously absent in chemistry.

[95] Bensaud-Vincent cites Duhem's discussion of the new chemical compound and revival of the Aristotelian term 'mixt' and other related concepts contra the atomistic and mechanistic paradigm. Thus Duhem, in Le mixte et la combinaison chimique, argues that in 'this mixt, the elements no longer have any actual existence. They exist there only potentially because on destruction the mixt can regenerate them' (cited in Bensaud-Vincent 2005, 637).

[96] The distinction between physics and chemistry, a political order of rank, seems to have made all the political, theoretical difference for the scientific estimation and investigation of the first reports of cold fusion inasmuch as these reports were made by scientists who happened to be not physicists but chemists. Mainstream philosophy of science continues to regard cold fusion as an example either of pseudo-science or fraud or something in-between.

[97] Leonardo, of course, likewise wrote on geology. See on Uzielli and Leonardo in addition to the texts cited above, Veltman 1986. On Lyell in geology see R. Porter 1976.

[98] Jobert also published a French and English version of Jobert 1846. See too Gillispie 1951, as well as Harré 2000. And see too Frodeman 1995.

[99] The name suggests the uniformitarian theory of geology assumes the constancy of the earth's relative position in the solar system and the stability of the geological features of the earth itself over long periods of time.

[100] The dependency of geologists on approaches to the philosophy of science deriving from analytic philosophy, as Frodeman notes is evident in Baker 1998.

[101] It is worth emphasizing that both Poincaré and Nietzsche's theories of recurrence (and the direction of Nietzsche's affirmation of fate emphasize not future possibility but an already consummate past.

[102] Of course such an acceptance was more reclamation than vindication. See Hallam 1973 as well as, for an insightful assessment, Harré 2000.

[103] Herbert 1983, Secord 1991, as well as more generally, Secord 1986. 
[104] See for example Rudwick 1985. This hardly means that historians of science are happy about any sort of sociological turn regarded as strong (Edinburgh is a synonym). See Bowler 1988 for a review of Laudan 1987. And see Greene 1982 as well as his 1992.

[105] See Cloud 2001 and Forman 1987 and 1984. But also see Barth 2003 as well as Hacker 2005.

[106] See Dennis 2003. See for continental philosophies of geology, Frodeman 2003, Raab and Frodeman 2002, Foltz and Frodeman 2004.

[107] A listing of literature in this field is instructive. For geography between 1890 and 1920, see S. Harrison 2005 and Rhoads 1999 and Rhoads and Thorn 1994 as well as Livingstone 2003. On phenomenology and geography, see Relph 2005 and Buttimer 1976; on hermeneutics and it is worth noting Livingstone's title change in the space of a year, see Livingstone 2002 and Mayhew 2007.

[108] See in addition to Forman's classic 1971 essay, his other work. The 'Forman thesis' has been applied beyond physics in Harwood 1996.

[109] A recent meeting of a society dedicated to the history of science centres on this project. But see, more conventionally, Kraft and Kroes 1984 as well as Schirrmacher 2002 and vom Bruch and Kaderas 2002.

[110] Some thirty years ago, Harrison could already point to an establishment and pro-presentist resistance to Buttterfield's contextualizing interpretation. See E. Harrison 1987. Resistance to Butterfield continues even in very sophisticated ways. See again, for example, Jardine 2003.

[111] See for a discussion and further references, Babich 2003b. Van den Belt and Gremmen 1990 invoke Fleck's own language of the 'serological' style of philosophic analysis: see in particular their discussion of the 'unity of style' (ibid., $467 \mathrm{ff}$.).

[112] In addition to the calculative advantage of mathematical analyses, the rhetoric and language of a code is key: crack the enemy code and win the battle. Change the genetic code and gain eternal life.

[113] See Babich 1994, especially on eco-physiology, 77-134 and on evolutionary psychology, Small 2005 and on physiology in Nietzsche's thought in general, see Moore 2002.

[114] In addition to many texts such as Richards 2005 discussing the conceptual influences on Darwin, see Gliboff 2008. It should go without saying that there is also a strong opposition but the historian Donald Worster (1994) underlines a case for such influences. See Sloan 2003 and, for a recent discussion, Costa 2009.

[115] See Reynolds 2008 for a discussion of Virchow's 'cell-state' in Haeckel's thinking; cf. Kleeberg 2005.

[116] See also Schweber 1977 and Conry 1983, and see too Lewontin 1991. Cf. with specific reference to Haeckel, Richards 2008.

[117] See J. Richardson 2004 as well as Moore 2002.

[118] See for a specific discussion of Nietzsche and Roux, Müller-Lauter 1999 but more influential on this topic, albeit via Bergson and Deleuze, has been Ansell-Pearson 1997. Those scholars who weigh the influences on Nietzsche (be it Roux or Haeckel), much as in another context one might emphasize Darwin's influence over Nietzsche's reading of Malthus, almost uniformly overlook the larger framework of the nineteenth-century scientific context in the process, a context we began by noting in its relevance in the specific context of the second law of thermodynamics for Nietzsche's theory of eternal recurrence.

[119] For many reasons, Haeckel's Kunstformen der Natur, originally published in 1898, has never been out of print. For a discussion see Breidbach 2006 as well as, again, Richards 2008.

[120] There are a number of discussions of such imaging techniques in science if it is also true that most of these take a very received view, e.g., Daston and Galison 2007. See too McAllister 1996.

[121] See Richards 2008, ch. 8.

[122] We have already cited Biberian 2007. Homeopathy continues to be rejected even when it is included among so-called alternative medicines such as acupuncture and Visvanathan 2006 has argued the very notion of an 'alternative' presupposes a dominant tradition. In addition to 
Luc Montagnier's argument on behalf of homeopathy, 'DNA Between Physics and Biology' at the July 2010 meeting of Nobel Laureates in Lindau, Germany see also Montagnier et al. 2009, see too Geckeler and Samal 2001 as well as Pearce and Rey 2007, both on the chemistry of 'ultra-high dilutions', which an older nomenclature named 'signatures'. For a classic essay (and a classic case of received opposition), see Benveniste 1988.

[123] Pinch points out that failure 'to replicate Moewus's findings could be put down to many factors, including whether other experimenters used the same strain of alga (part of the controversy concerned the very classification of Chlamydomonas), whether others cultivated the alga in the same way, and whether others followed Moewus's protocols exactly. Even when, near the end of the controversy, Moewus was unable to repeat his own findings, such results were not definitive, because by this stage Moewus's stocks were in poor condition, and he was having to produce results on the spot for sceptical scientists in a matter of months in a strange environment (Moewus by this time had no permanent academic position). By contrast, his previous results had been slowly built up in his laboratory in Germany over many years' (Pinch 1993, 365).

[124] Ernst Chladni, regarded as the father of meteoritics also explored visual acoustic patterns in sound, today called cymatics. See Chladni 2004 [1802]. On Chladni, see Ullmann 1996.

[125] In addition to the complex demands of pictorial hermeneutics in the biological tradition, see Kleeberg 2007 and Brannigan 1979.

[126] See Mach 2009 for a discussion, with reference to Haeckel, of the advantage of the pencil, and pen and ink imaging techniques, over computer graphics. See, further, Daston and Galison 2007.

[127] Although Gödel and Hilbert himself never did meet (nor is this surprising given the difference in age and indeed prestige), they were not unconnected given Gödel's friendship with Hilbert's assistant, Paul Bernays.

[128] Apart from its (undermining) relevance to Hilbert's program, there is some speculation concerning the relevance of Gödel's incompleteness theorem for Heisenberg's uncertainty principle, and the most promising discussions look to John von Neumann and his quantum measurement theory. Gödel and von Neumann, who had independently come to similar insights, first met in 1930, and thereafter enjoyed a long correspondence and intellectual friendship. See to begin with the contributions to Rédei and Stöltzner 2001.

[129] The one unifying characteristic of both popular and more recondite books on Gödel seems to be impatience with other treatments of Gödel both in philosophical literature, cultural studies, and indeed other books on Gödel.

[130] See for general context including a specific discussion of Cavaillès, Schrift 2006, 36ff.

[131] See Yourgrau 2005, 111ff., for a discussion, with reference to Schilpp, Einstein, and Putnam.

[132] It is worth noting that the Asian philosopher and sociologist of science, Shiv Visvanathan, describes these general debates as concerning 'the politics of the axiomatization of knowledge itself. See Visvanathan 2006, 164.

[133] See Sandbothe 1994 and, for further reading, the selections in Zimmerli and Sandbothe 1993.

\section{References}

Adorno, T. W., and M. Horkheimer. 2002. Dialectic of enlightenment. Translated by E. Jephcott. Stanford, CA: Stanford University Press.

Alder, K. 2002. The history of science, or an oxymoronic theory of relativistic objectivity. In $A$ companion to Western historical thought, edited by L. Kramer and S. Maza, 297-318. Oxford: Blackwell.

Ansell-Pearson, K. 1994. An introduction to Nietzsche as political thinker. Cambridge: Cambridge University Press.

1997. Viroid life: Perspectives on Nietzsche and the transhuman condition. London: Routledge. 
Anstee, M. 2006. The relevance of Nietzsche: A Nietzschean critique of popular ideals in social theory and sociology. PhD dissertation, University of Queensland.

Arens, K. 1988. Structures of knowing: Psychologies of the nineteenth century. Dordrecht: Kluwer.

Arrowsmith, W. 1974 [1973]. Nietzsche: Notes for 'We philologists'. Arion, n.s., 1-2: 279-380.

Avenarius, R. 1889 [1888]. Kritik der reinen Erfahrung. Leipzig: O. R. Reisland.

Babich, B. 1993. Mach, Duhem, Bachelard. In Twentieth-century continental philosophy, edited by R. Kearney, 175-221. London: Routledge.

—. 1994. Nietzsche's philosophy of science: Reflecting science on the ground of art and life. Albany, NY: State University of New York Press.

- 2002. Sokal's hermeneutic hoax: Physics and the new inquisition. In Hermeneutic philosophy of science, van Gogh's eyes, and God, edited by B. Babich, 67-78. Dordrecht: Kluwer.

- 2003a. On the analytic-continental divide in philosophy: Nietzsche's lying truth, Heidegger's speaking language, and philosophy. In A house divided: Comparing analytic and continental philosophy, edited by C. G. Prado, 63-103. Amherst, NY: Humanity Books.

—. 2003b. From Fleck's Denkstil to Kuhn's paradigm: Conceptual schemes and incommensurability. International Studies in the Philosophy of Science 17: 75-92.

- 2005. The science of words or philology: Music in The birth of tragedy and the alchemy of love in The gay science. Rivista di estetica, n.s., 28: 47-78.

- 2007a. Continental philosophy of science. In Edinburgh companion to twentieth-century philosophies, edited by C. Boundas, 545-558. Edinburgh: University of Edinburgh Press.

- 2007b. 'The problem of science' in Nietzsche and Heidegger. Revista Portuguesa de la Filosofia 63: 205-237.

- 2009a. Jaspers, Heidegger, and Arendt: On politics, science, and communication. Existenz 4, no. $1: 1-19$.

— 2009b. Nietzsche's philology and Nietzsche's science: On the 'Problem of science' and 'fröhliche Wissenschaft'. In Metaphilology: Histories and languages of philology, edited by P. Hummel, 155-201. Paris: Philologicum.

—. 2010a. Nietzsches Wissenschaftsphilosophie: 'Die Wissenschaft unter der Optik des Künstlers zu sehn, die Kunst aber unter der des Lebens'. Bern: Peter Lang.

—. 2010b. Das 'Problem der Wissenschaft' oder Nietzsches philosophische Kritik wissenschaftlicher Vernunft. In Der Tod Gottes und die Wissenschaft: Zur Wissenschaftskritik Nietzsches, edited by C. Gentili and K. Nielsen, 125-171. Berlin: Walter de Gruyter.

- 2010c. Ex aliquo nihil: Nietzsche on science and modern nihilism. American Catholic Philosophical Quarterly 84: 231-256.

- 2010d. Early continental philosophy of science. In The new century, vol. 3: History of continental philosophy, edited by A. Schrift, 263-286. Chesham: Acumen Press.

- Forthcoming. Nietzsche and Darwin. Common Knowledge.

Babich, B., and R. S. Cohen, eds. 1999a. Nietzsche, theories of knowledge and critical theory: Nietzsche and the sciences, vol. 1. Dordrecht: Kluwer.

— - eds. 1999b. Nietzsche, epistemology and philosophy of science: Nietzsche and the sciences, vol. 2. Dordrecht: Kluwer.

Bachelard, G. 1970. Preface to the 1960 edn (of J. Cavaillès, Sur la logique et la théorie de la science). In Phenomenology and the natural sciences, edited by J. J. Kockelmans and T. J. Kisiel, 353-354. Evanston, IL: Northwestern University Press.

Baker, V. R. 1998. Catastrophism and uniformitarianism: Logical roots and current relevance in geology. In Lyell: The past is the key to the present, edited by D. J. Blundell and A. C. Scott, 171-182. London: Geological Society.

Banks, E. 2003. Ernst Mach's world elements: A study in natural philosophy. Dordrecht: Kluwer.

- 2004. The philosophical roots of Ernst Mach's economy of thought. Synthese 139: 23-53.

Barth, K.-H. 2003. The politics of seismology. Social Studies of Science 33: 743-781.

Basso, L. 1925. Induction technique et science expérimentale. Revue philosophique de la France et de l'étranger 99: 41-76. 
Belt, H. van den, and B. Gremmen. 1990. Specificity in the era of Koch and Ehrlich: A generalized interpretation of Ludwik Fleck's 'serological' thought style. Studies in History and Philosophy of Science 21: 463-479.

Benne, C. 2005. Nietzsche und die historisch-kritische Philologie. Berlin: Walter de Gruyter.

Bensaud-Vincent, B. 2005. Chemistry in the French tradition of philosophy of science: Duhem, Meyerson, Metzger and Bachelard. Studies in History and Philosophy of Science 36: 627-649.

Benveniste, J. 1988. Human basophil degranulation triggered by very dilute antiserum against IgE. Nature 334: 816-818.

Biberian, J. 2007. Condensed matter nuclear science cold fusion: An update. International Journal of Nuclear Energy Science and Technology 3: 31-42.

Boime, A. 1993. The art of the Macchia and the Risorgimento. Chicago, IL: University of Chicago Press.

Bontempelli, C. 2004. Knowledge, power, and discipline: German studies and national identity. Minneapolis: University of Minnesota Press.

Boone, D. N. 1999. The cogent reasoning model of informal fallacies. Informal Logic 19: 1-39.

Boundas, C. 2007. How to recognize continental European philosophy. In Edinburgh companion to twentieth-century philosophies, edited by C. Boundas, 367-374. Edinburgh: University of Edinburgh Press.

Bowler, P. J. 1988. The Whig interpretation of geology. Biology and Philosophy 3: 99-103.

Boyer, A. 1992. Physique de croyant? Duhem et l'autonomie de la science. Revue internationale de philosophie 46: 311-322.

Brakel, J. van. 1997. Chemistry as the science of the transformation of substances. Synthese 111: 253-282.

- 1999. On the neglect of the philosophy of chemistry. Foundations of Chemistry 1:111-174.

- 2002. Philosophy of chemistry. Leuven: Leuven University Press.

Brannigan, A. 1979. The reification of Gregor Mendel. Social Studies of Science 9: 423-454.

Breidbach, O. 2006. Visions of nature: The art and science of Ernst Haeckel. Munich: Prestel.

Brobjer, T. H. 2007. Nietzsche's relation to historical methods and nineteenth-century German historiography. History and Theory 46: 155-179.

—. 2008. Nietzsche's philosophical context: An intellectual biography. Urbana: University of Illinois Press.

Brobjer, T. H., and G. Moore, eds. 2004. Nietzsche and science. Aldershot: Ashgate.

Bruch, R. vom, and B. Kaderas, eds. 2002. Wissenschaften und Wissenschaftspolitik. Bestandsaufnahmen $z u$ Formationen. Stuttgart: Steiner.

Brush, S. 1968. Mach and atomism. Synthese 18: 192-215.

- 1978. The temperature of history: Phases of science and culture in the nineteenth century. New York: Burt Franklin.

Bucchi, M. 2004. Science in society: An introduction to social studies of science. Translated by A. Belton. New York: Routledge.

Butterfield, H. 1931. The Whig interpretation of history. New York: W. W. Norton.

Buttimer, A. 1976. Grasping the dynamism of the lifeworld. Annals of the Association of American Geographers 66: 277-292.

Cahan, D. 2003. From natural philosophy to the sciences: Writing the history of nineteenth-century science. Chicago, IL: University of Chicago Press.

Camilleri, C. 2009. Heisenberg and the interpretation of quantum mechanics: The physicist as philosopher. Cambridge: Cambridge University Press.

Carroll, L. 1895. What the tortoise said to Achilles. Mind 104: 691-693.

Cassirer, E. 2000. The individual and the cosmos in Renaissance philosophy. Translated by M. Domandi. New York: Dover.

Cavaillès, J. 1970. On logic and the theory of science. In Phenomenology and the natural sciences, edited by J. J. Kockelmans and T. J. Kisiel, 353-409. Evanston, IL: Northwestern University Press. 
Chimisso, C. 2001. Gaston Bachelard: Critic of science and the imagination. London: Routledge.

Chladni, E. F. F. 2004 [1802]. Die Akustik. Hildesheim: Olms.

Cloud, J. 2001. Imaging the world in a barrel: CORONA and the clandestine convergence of the earth sciences. Social Studies of Science 31: 231-251.

Cohen, H. F. 1994. The scientific revolution: A historiographical inquiry. Chicago, IL: University of Chicago Press.

Cohen, R. S. 1968. Ernst Mach: Physics, perception and the philosophy of science. Synthese 18: 126-164.

Conry, Y., ed. 1983. De Darwin au darwinisme: Science et idéologie. Paris: Vrin.

Constable, M. 1994. Genealogy and jurisprudence: Nietzsche, nihilism, and the social scientification of law. Law and Social Inquiry 19: 551-590.

Cooper, A. 2010. Inventing the indigenous: Local knowledge and natural history in early modern Europe. Cambridge: Cambridge University Press.

Costa, J. T. 2009. The Darwinian revelation: Tracing the origin and evolution of an idea. BioScience 59: 886-894.

Couprie, D., R. Hahn, and G. Naddaf. 2003. Anaximander in context: New studies in the origins of Greek philosophy. Albany: State University of New York Press.

Crombie, A. 1950. Augustine to Galileo, A.D. 400-1650. London: Falcon Press.

- 1970. Robert Grosseteste and the origins of experimental science. Oxford: Clarendon Press.

1994. Styles of scientific thinking in the European tradition: The history of argument and explanation especially in the mathematical and biomedical sciences and arts. London: Duckworth.

Cunningham, A. 1988. Getting the game right: Some plain words on the identity and invention of science. Studies in History and Philosophy of Science 19: 365-389.

Dahlstrom, D. 2001. Heidegger's concept of truth. Cambridge: Cambridge University Press.

Danto, A. 2000. Riegl bearing. Artforum International 39: 21-22.

Darwin, C. 1864. On the origin of the species by means of natural selection; or the preservation of favoured races in the struggle for life. New York: D. Appleton.

—. 1867. Über die Entstehung der Arten um Their- und Pflanzen-Reich durch natürliche Züchtung, oder Erhaltung der vervollkemmneten Rassen im Kampfe um's Daseyn. Translated by H. G. Bronn. Stuttgart: E. Schweizerbart.

Daston, L., and P. Galison. 2007. Objectivity. Cambridge, MA: Zone Books.

Dastur, F. 2006. Le concept de science chez Heidegger avant le 'tournant' des années trente. Noesis 9: $8-28$.

Davis, R. 2003. The microbial models of molecular biology. Oxford: Oxford University Press.

Dear, P. 1995. Discipline and experience: The mathematical way in the scientific revolution. Chicago, IL: University of Chicago Press.

- 2001. Revolutionizing the sciences: European knowledge and its ambitions, 1500-1700. Princeton, NJ: Princeton University Press.

Denker, A., and H. Zaborowski, eds. 2006. Heidegger und die Logik. Amsterdam: Rodopi.

Dennett, D. 1996. Darwin's dangerous idea. London: Penguin.

Dennis, M. A. 2003. Earthly matters: On the cold war and the earth sciences. Social Studies of Science 33: 809-819.

Dessoir, M. 1927. Kunstgeschichte und Kunstsystematik. Zeitschrift für Ästhetik und allgemeine Kunstwissenschaft 21: 131-142.

Dijkgraaf, R. 2008. Mathematical connections. Nieuw archief voor wiskunde 59, no. 2: 97-98.

Dingle, H., and G.R. Martin with E. Paneth. 1964. Chemistry and beyond: A selection from the writings of the late professor F. A. Paneth. New York: Wiley-Interscience.

Dobbs, B. J. T. 1975. The foundations of Newton's alchemy, or 'The hunting of the greene lyon'. Cambridge: Cambridge University Press. 1991. Janus face of genius: The role of alchemy in Newton's thought. Cambridge: Cambridge University Press. 
Donohue, A. A. 2006. Greek sculpture and the problem of description. Cambridge: Cambridge University Press.

Drachmann, A. G. 1963. The mechanical technology of Greek and Roman antiquity. Madison: University of Wisconsin Press.

Drake, S. 1989. History of free fall: Aristotle to Galileo. Toronto: Wall \& Thompson.

Duesberg, P. 1995. Inventing the AIDS virus. Washington, DC: Regnery.

Duesberg, P., C. Koehnlein, and D. Rasnick. 2003. The chemical bases of the various AIDS epidemics: Recreational drugs, anti-viral chemotherapy and malnutrition. Journal of BioScience 28: 383-412.

Duhem, P. 1906. Études sur Leonard de Vinci: Ceux qu'il a lus et ceux qui l'ont lu. Paris: A. Hermann.

__ 1959 [1913]. Le Système du monde: Histoire des doctrines cosmologiques de Platon à Copernic. Paris: A. Hermann.

- 2003. German science. La Salle, IL: Open Court.

Duplouy, A. 2006. Le Prestige des élites: Recherches sur les modes de reconnaissance sociale en Grèce entre les Xe et Ve siècles avant J.-C. Paris: Les Belles Lettres.

Eco, U. 2007. Turning back the clock: Hot wars and media populism Translated by A. McEwen. New York: Houghton Mifflin Harcourt.

Eiseley, L. 1961. Darwin's century: Evolution and the men who discovered it. New York: Anchor.

Epple, M. 2006. Felix Hausdorff's considered empiricism. In The architecture of modern mathematics, edited by J. Ferreirós and J. Gray. Oxford: Oxford University Press, 263-290.

Feyerabend, P. K. 1978. Science in a free society. London: Verso.

- 1984. Mach's theory of research and its relation to Einstein. Studies in History and Philosophy of Science 15: 1-22.

- 1989. Farewell to reason. London: Verso.

Fleck, L. 1979. The genesis and development of a scientific fact. Translated by F. Bradley and T. Trenn. Chicago, IL: University of Chicago Press.

Fleischmann, E. 1964. De Weber à Nietzsche. Archives Européennes de Sociologie 5: 190-238.

Flyvbjerg, B. 2007. Making social science matter: Why social inquiry fails and how it can succeed again. Cambridge: Cambridge University Press.

Foltz, B., and R. Frodeman, eds. 2004. Rethinking nature: Essays in environmental philosophy. Bloomington: Indiana University Press.

Forman, P. 1971. Weimar culture, causality, and quantum theory, 1918-1927: Adaptation by German physicists and mathematicians to a hostile intellectual environment. Historical Studies in the Physical Sciences 3: 1-115.

-1984. Kausalität, Anschaulichkeit, and Individualität, or how cultural values prescribed the character and the lessons ascribed to quantum mechanics. In Society and knowledge: Contemporary perspectives in the sociology of knowledge, edited by N. Stehr and V. Meja, 333-347. New Brunswick, NJ: Transaction Books.

—. 1987. Behind quantum electronics: National security as basis for physical research in the United States, 1940-1960. Historical Studies in the Physical and Biological Sciences 18: 149-229.

Fort, C. H. 1919. The book of the damned. New York: Boni \& Liveright.

Freudenthal, G. 1988. Maimonides' Guide of the perplexed and the transmission of the mathematical tract 'On the asymptotic lines' in the Arabic, Latin, Hebrew medieval tradition. Vivarium 26: $113-140$.

1993. Sauver son âme ou sauver les phénomènes: Sotérologie, épistémologie et astronomie chez Gersonide. In Studies on Gersonides, edited by G. Freudenthal, 317-352. Leiden: Brill.

Friday, J. 1998. Hume's sceptical standard of taste. Journal of the History of Philosophy 36: 545-566.

Friedman, M. 1999. Reconsidering logical positivism. Cambridge: Cambridge University Press.

- 2000. Parting of the ways: Carnap, Cassirer, Heidegger. Chicago, IL: Open Court.

Frodeman, R. 1995. Geological reasoning: Geology as an interpretive and historical science. GSA Bulletin 107: 960-968. 
- 2003. Geo-logic: Breaking ground between philosophy and the earth sciences. Albany: State University of New York Press.

Gadamer, H.-G. 2004. Truth and method, Translated by J. Weinsheimer. London: Continuum.

Gallo, R. C. 1991. Virus hunting: AIDS, cancer, and the human retroviruses. A story of scientific discovery. New York: Basic Books.

Geckeler, K., and S. Samal. 2001. Unexpected solute aggregation in water on dilution. Chemical Communications 21: 2224-2225.

Gentili, C., and K. Nielsen, eds. 2010. Der Tod Gottes und die Wissenschaft: Zur Wissenschaftskritik Nietzsches. Berlin: Walter de Gruyter.

Gethmann-Siefert, A., and J. Mittelstrass, eds. 2002. Die Philosophie und die Wissenschaften: Zum Werk Oskar Beckers. Munich: Fink.

Giere, R., and A. Richardson, eds. 1996. Origins of logical empiricism. Minneapolis: University of Minnesota Press.

Gillispie, C. C. 1951. Genesis and geology. Cambridge, MA: Harvard University Press.

Ginzburg, C. 2004. Family resemblances and family trees: Two cognitive metaphors. Critical Inquiry 30: 537-556.

Giugliano, A. 2005. Zahl und Zeit: Becker zwischen Nietzsche und Heidegger. In Oskar Becker und die Philosophie der Mathematik, edited by V. Peckhaus, 47-53. Munich: Wilhelm Fink Verlag.

Glazebrook, P. 2000. Heidegger's philosophy of science. New York: Fordham University Press.

Gliboff, S. 2008. H. G. Bronn, Ernst Haeckel, and the origins of German Darwinism: A study in translation and transformation. Cambridge, MA: MIT Press.

Glucker, J. 1996. J. Lachmann's method-Bernays, Madvig, Lachmann, and others. In Jacob Bernays un philologue juif, edited by J. Glucker and A. Laks, 45-56. Villeneuve d'Ascq: Presses Universitaires du Septentrion.

Gödel, K. 1949. A remark about the relationship between relativity theory and idealistic philosophy. In Albert Einstein: Philosopher-scientist, edited by P. A. Schilpp, 555-562. La Salle, IL: Open Court.

- 1962. On formally undecidable propositions of Principia mathematica and related systems. New York: Dover.

Gori, P. 2009. The usefulness of substances: Knowledge, science and metaphysics in Nietzsche and Mach. Nietzsche-Studien 38: 111-155.

Greenberg, D. S. 2001. Science, money, and politics: Political triumph and ethical erosion. Chicago, IL: University of Chicago Press.

Greene, M. 1982. Geology in the nineteenth century: Changing views of a changing world. Cambridge, MA: MIT Press.

—. 1992. Natural knowledge in preclassical antiquity. Ithaca, NY: Cornell University Press.

Grondin, J. 2000. Continental or hermeneutical philosophy: The tragedies of understanding in the analytic and continental perspectives. In Interrogating the tradition: Hermeneutics and the history of philosophy, edited by C. Scott and J. Sallis, 75-83. Albany: State University of New York Press.

Grosz, E. A. 1994. Volatile bodies. Bloomington: Indiana University Press.

Gutting, G., ed. 2005. Continental philosophy of science. Oxford: Blackwell.

Hacker, B. 2005. The machines of war: Western military technology 1850-2000. History and Technology 21: $255-300$.

Hacker, P. M. S. 2006. Soame's history of analytic philosophy. Philosophical Quarterly 56: 121-131.

Haeckel, E. 1866. Generelle Morphologie der Organismen: Allgemeine Gründzüge der organischen Formen-Wissenschaft, mechanisch begründet durch die von Charles Darwin reformierte Decendenz-Theorie. Berlin: Reimer.

- 1998. Art forms in nature. London: Prestel.

Hallam, A. 1973. A revolution in the earth sciences: From continental drift to plate tectonics. Oxford: Clarendon Press. 
Haller, R. 1982. Poetic imagination and economy: Ernst Mach as theorist of science. In Scientific philosophy today: Essays in honor of Mario Bunge, edited by J. Agassi and R. S. Cohen, 71-84. Dordrecht: Reidel.

Hands, D. W. 2003. 'You want the social? You can't handle the social!': Mirowski on the secret history of scientific philosophy. Studies in History and Philosophy of Science 36: 726-733.

Harden, V. 1992. Koch's postulates and the etiology of AIDS: An historical perspective. History and Philosophy of the Life Sciences 14: 249-269.

Harré, R. 1989 [1972]. The philosophies of science. Oxford: Oxford University Press.

- 2000. Philosophy and geology. In The Oxford companion to the earth, edited by P. Hancock and B. J. Skinner, 821-822. Oxford: Oxford University Press.

Harris, E. 2001. Chlamydomonas as a model organism. Annual Review of Plant Physiology and Plant Molecular Biology 52: 363-406.

Harrison, E. 1987. Whigs, prigs and historians of science. Nature 329: 213-214.

Harrison, S. 2005. What kind of a science is physical geography? In Questioning geography, edited by N. Castree, A. Rogers, and D. Sherman, 80-95. Oxford: Blackwell.

Hart, J. 1982. Reinterpreting Wölfflin: Neo-Kantians and hermeneutics. Art Journal 42: 293-300.

Harwood, J. 1996. Weimar culture and biological theory: A study of Richard Woltereck, 1877-1944. History of Science 34: 347-77.

Heelan, P. A. 1965 Quantum mechanics and objectivity: A study of the physical philosophy of Werner Heisenberg. The Hague: Nijhoff.

_ 1975 Heisenberg and radical theoretic change. Zeitschrift für allgemeine Wissenschaftstheorie 6: 113-138.

- 1995. Heidegger's longest day: Twenty-five years later. In From phenomenology to thought, errancy, and desire, edited by B. Babich, 579-588. Dordrecht: Kluwer.

- 2004. The phenomenological role of consciousness in measurement. Mind and Matter 2: 61-84.

Heidegger, M. 1985. History of the concept of time. Translated by T. J. Kisiel. Indianapolis: Indiana University Press.

Hempel, C. 1990. Natur und Geschichte: Der Jahrhundertdialog zwischen Heidegger und Heisenberg. Frankfurt am Main: Anton Hain.

Henke, D. 1984. Nietzsches Darwinismuskritik aus der Sicht gegenwärtiger Evolutionsforschung. Nietzsche-Studien 13: 189-210.

Hentschel, K. 2003. Der Vergleich als Brucke zwischen Wissenschaftsgeschichte und Wissenschaftstheorie. Journal for General Philosophy of Science 34: 251-275.

Herbert, S. 1983. Charles Darwin, geologist. Ithaca, NY: Cornell University Press.

Hilbert, D. 1902. Mathematical problems. Bulletin of the American Mathematical Society 8: 437-479.

Hintikka, J. 1987. The fallacy of fallacies. Argumentation 1: 211-238.

Hoenigswald, H. 1995. Zu Leben und Werk Richard Hönigswald. In Erkennen-Monas—Sprache, edited by W. Schmied-Kowarzik, 425-435. Würzburg: Königshausen \& Neumann.

Holton, G. 1978. Dionysians, Apollonians, and the scientific imagination. In G. Holton, The scientific imagination: Case studies. Cambridge: Cambridge University Press, 87-110.

Howard, D. 1990. Einstein and Duhem. Synthese 83: 363-384.

Hume, D. 1757. Four dissertations: I. The natural history of religion. I I. Of the passions. III. Of tragedy. IV. Of the standard of taste. London: A. Milar.

—. 1965a. Of the standard of taste. In Hume's ethical writings. edited by A. Macintyre. New York: Collier.

- 1965b. On the standard of taste and other essays. Indianapolis, IN: Bobbs-Merrill.

Irigaray, L. 1985. Is the subject of science sexed? Translated by E. Oberle. Cultural Critique 1: $73-88$.

Jaki, S. L. 1988. Science and censorship: Hélène Duhem and the publication of the Système du monde. In S. L. Jaki, The absolute beneath the relative and other essays. Lanham, MD: University Press of America.

—. 1991. Pierre Duhem: Homme de foi et de science. Paris: Beauchesne. 
2006. A late awakening to Gödel in physics. In S. L. Jaki, A late awakening and other essays. New Hope, KY: Real View Books, 1-12.

Jardine, N. 2003. Whigs and stories: Herbert Butterfield and the historiography of science. History of Science 41: 124-140.

Jaspers, K. 1997. Nietzsche: An introduction to the understanding of his philosophical activity. Translated by C. F. Wallraff and F. J. Schmitz. Baltimore, MD: Johns Hopkins University Press.

Jay, M. 1986. Marxism and totality: The adventures of a concept from Lukács to Habermas. Berkeley: University of California Press.

Jobert, A. C. G. 1846. Philosophy of geology. London: Simpkin, Marshall \& Co.

Kahn, C. 1960. Anaximander and the origins of Greek cosmology. Oxford: Oxford University Press.

Käufer, S. 2001. On Heidegger on logic. Continental Philosophy Review 34: 455-476.

Kerszberg, P. 1986. Sur la physique et la phénoménologie de Hermann Weyl. Études Phénoménologiques 3: 3-31.

Kisiel, T. J. 1993. The genesis of Heidegger's 'Being and Time'. Berkeley: University of California Press.

Kleeberg, B. 2005. Theophysis: Ernst Haeckels Philosophie des Naturganzen. Weimar: Böhlau.

— 2007. Dr. Haeckel and Mr. Hyde: New works on 19th- and 20th-century German biology and anthropology. Nuncius 22: 125-138.

Kraft, P., and P. Kroes. 1984. Adaptation of scientific knowledge to an intellectual environment. Paul Forman's 'Weimar culture, causality, and quantum theory, 1918-1927': Analysis and criticism. Centaurus 27: 76-99.

Kristeller, O. 1981. The Lachmann method: Merits and limitations. Text 1, 11-20.

Ladrière, J. 1970. Mathematics and formalism. In Phenomenology and the natural sciences, edited by J. J. Kockelmans and T. J. Kisiel, 469-470. Evanston, IL: Northwestern University Press.

Latour, B. 1999. Pandora's hope: Essays on the reality of science studies. Cambridge, MA: Harvard University Press.

Laudan, R. 1987. From mineralogy to geology: The foundations of a science, 1650-1830. Chicago, IL: University of Chicago Press.

Leck, R. M. 2000. Georg Simmel and avant-garde sociology: The birth of modernity, 1880-1920. Amherst, NY: Humanity Books.

Lejbowicz, M. 2004. Pierre Duhem et l'histoire des sciences arabes. Revue des Questions Scientifiques 175: 59-84.

Levins, R., and R. C. Lewontin. 1985. The dialectical biologist. Cambridge, MA: Harvard University Press.

Lewontin, R. C. 1991. Biology as ideology: The doctrine of DNA. Toronto: House of Anansi.

Liegener, C., and G. Del Re. 1987. Chemistry versus physics, the reduction myth, and the unity of science. Zeitschrift für allgemeine Wissenschaftstheorie 18: 165-174.

Livingstone, D. N. 2002. Science, space and hermeneutics. Hettner Lecture, University of Heidelberg.

- 2003. Putting science in its place: Geographies of scientific knowledge. Chicago, IL: University of Chicago Press.

Mach, M. 2009. Schmucker Winzling—Das Bartierchen Calohypsibius ornatus. Mikrokosmos 98:9-15.

Maclachlan, C. 1986. Hume and the standard of taste. Hume Studies 12: 18-38.

Malinowski, B. 1993. Observations on Friedrich Nietzsche's The birth of tragedy. In The early writings of Bronislaw Malinowski, edited by R. J. Thornton and P. Skalnik, 67-88. Cambridge: Cambridge University Press.

Martelaere, P. de. 1989. A taste for Hume. Ratio, n.s., 2: 122-137.

Martin, R. D. D. 1991. Pierre Duhem: Philosophy and history in the work of a believing physicist. LaSalle, IL: Open Court.

Mauss, M. 1924. Gift, gift. In Mélanges offerts à M. Charles Andler par ses amis et ses élèves, 243-247. Strasbourg: Librarie Istria.

Mayhew, R. J. 2007. Materialist hermeneutics, textuality and the history of geography: Print spaces in British geography, c. 1500-1900. Journal of Historical Geography 33: 466-488.

McAllister, J. W. 1996. Beauty and revolution in science. Ithaca, NY: Cornell University Press. 
Mirowski, P. 2004. The effortless economy of science. Durham, NC: Duke University Press.

Mittasch, A. 1942a. Der Kraftbegriff bei Leibniz, Robert Mayer, Nietzsche. Proteus 3: 69-76.

—. 1942b. Friedrich Nietzsches Verhältnis zu Robert Mayer. Blätter für Deutsche Philosophie 16: 139-161.

-1944. Nietzsches Stellung zur Chemie. Berlin: Verlag Chemie.

-1952. Nietzsche als Naturphilosoph. Stutttgart: Kroner.

Mongré, P. [F. Hausdorff]. 1897. Sant'Ilario: Gedanken aus der Landschaft Zarathustras. Leipzig: C. G. Naumann.

Montagnier, L., J. Aïssa, S. Ferris, J.-L. Montagnier, and C. Lavallée. 2009. Electromagnetic signals are produced by aqueous nanostructures derived from bacterial DNA sequences. Interdisciplinary Sciences: Computational Life Sciences 1: 1913-2751.

Moore, G. 2002. Nietzsche, biology and metaphor. Cambridge: Cambridge University Press.

Mossner, E. C. 1950. Hume's 'Four dissertations': An essay in biography and bibliography. Modern Philology 48: 37-57.

Müller, C. W. 2009. Nachlese: Kleine Schriften 2. Berlin: Walter de Gruyter.

Müller-Lauter, W. 1999. The organism as inner struggle: The influence of Wilhelm Roux on Friedrich Nietzsche. In Nietzsche: The philosophy of contradictions and the contradictions of his philosophy. Translated by D. Parent, 161-182, 230-241. Urbana: University of Illinois Press.

Mulligan, K. 1991. On the history of continental philosophy. Topoi 10, no. 2: 115-120.

- 1998. The great divide. Times Literary Supplement, 26 June: 6-8.

Newton-Smith, W. H. 1981. The rationality of science. London: Routledge and Kegan Paul.

Nietzsche, F. 1980. Sämtliche Werke, 15 vols. Edited by G. Colli and M. Montinari, 247-412. Berlin: Walter de Gruyter, vol. 5.

- 1994. Frühe Schriften, vol. 5: Schriften der letzten Leipziger und ersten Basler Zeit 1868-1869, edited by C. Koch and K. Schlechta. Munich: Beck.

Nye, A. 1990. Words of power: A feminist reading of the history of logic. New York: Routledge.

Oleson, J., ed. 2008. The Oxford handbook of engineering and technology in the classical world. New York: Oxford University Press.

Onians, J. 1978. Art history, Kunst-Geschichte, and historia. Art History 1, no. 2: 131-133.

Owen, D. 1994. Maturity and modernity: Nietzsche, Weber, Foucault and the ambivalence of reason. London: Routledge.

Paneth, F. 2003. The epistemological status of the chemical concept of element. Foundations of Chemistry 5: 113-145.

Pearce, J., and L. Rey. 2007. Can low-temperature thermoluminescence cast light on the nature of ultra-high dilutions? Homeopathy 96, no. 3: 170-174.

Peiffer, J. 2002. France. In Writing the history of mathematics, edited by J. W. Dauben and C. J. Scriba, 3-44. Basel: Birkhäuser.

Peters, M. 2007. Wittgenstein, education and the philosophy of mathematics. Linguistic and Philosophical Investigations 7: 13-25.

Pieper, H.-J. 2002. Musils Philosophie: Essayismus und Dichtung im Spannungsfeld der Theorien Nietzsches und Machs. Würzburg: Königshausen \& Neumann.

Pilkey, O. H., and L. Jarvis. 2007. Useless arithmetic: Why environmental scientists can't predict the future. New York: Columbia University Press.

Pinch, T. 1993. Generations of SSK. Social Studies of Science 23: 363-373.

Podolsky, S. H., and A. I. Tauber. 1999. Nietzsche's conception of health: The idealization of struggle. In Nietzsche, epistemology and the philosophy of science: Nietzsche and the sciences, vol. 2, edited by B. Babich and R. S. Cohen, 299-311. Dordrecht: Kluwer.

Poincaré, H. 1905. Science and hypothesis. London: Walter Scott Publishing.

Porter, J. 2000. Nietzsche and the philology of the future. Stanford, CA: Stanford University Press.

Porter, R. 1976. Charles Lyell and the principles of the history of geology. British Journal for the History of Science 9: 94-96.

Preston, A. 2000. Analytic philosophy: The history of an illusion. London: Continuum. 
Principe, L. 1998. The aspiring adept: Robert Boyle and his alchemical quest. Princeton, NJ: Princeton University Press.

- 2004. Reflections on Newton's alchemy in light of the new historiography of alchemy. In Newton and Newtonianism, edited by J. E. Force and S. Hutton, 205-219. Dordrecht: Kluwer.

Proctor, R. N. 1995. Cancer wars: How politics shapes what we know and don't know about cancer. New York: Basic Books.

Raab, T., and R. Frodeman. 2002. What is it like to be a geologist? A phenomenology of geology and its epistemological implications. Philosophy and Geography 5: 69-81.

Ragep, F. J. 1990. Duhem, the Arabs, and the history of cosmology. Synthese 83: 210-214.

Rajan, R. 2005. Science, state, and violence: An Indian critique considered. Science as Culture 14, no. 3: 265-281.

Rédei, M., and M. Stöltzner, eds. 2001. John von Neumann and the foundations of quantum physics. Dordrecht: Springer.

Reinert, H., and E. S. Reinert. 2006. Creative destruction in economics: Nietzsche, Sombart, Schumpeter. In Friedrich Nietzsche 1844-2000: Economy and society, edited by J. Backhaus and W. Drechsler, 55-85. Dordrecht: Kluwer.

Relph, E. C. 2005. An inquiry into the relations between phenomenology and geography. Canadian Geographer 143: 193-201.

Reynolds, A. 2008. Ernst Haeckel and the theory of the cell state. History of Science 46: 123-152.

Rhoads, C. L. 1999. Beyond pragmatism: The value of philosophical discourse for physical geography. Annals of the Association of American Geographers 89: 760-777.

Rhoads, C. L., and C. E. Thorn. 1994. Contemporary philosophical perspectives on physical geography with emphasis on geomorphology. Geographical Review 84: 90-101.

Ribeck, O. 1878-81. Friedrich Wilhlem Ritschl: Ein Beitrag zur Geschichte der Philologie. Two volumes. Leipzig: Teubner.

Richards, R. J. 2002. The linguistic creation of man: Charles Darwin, August Schleicher, Ernst Haeckel, and the missing link in nineteenth-century evolutionary theory. In Experimenting in tongues: Studies in science and language, edited by M. Dörries, 21-48. Stanford, CA: Stanford University Press.

— 2005. Darwin's metaphysics of mind. In Darwin and philosophy, edited by V. Hösle and C. Illies, 166-180. Notre Dame, IN: Notre Dame University Press.

- 2008. The tragic sense of life: Ernst Haeckel and the struggle over evolution. Chicago, IL: University of Chicago Press.

Richardson, J. 2004. Nietzsche's new Darwinism. Oxford: Oxford University Press.

Richardson, W. J. 1968. Heidegger's critique of science. New Scholasticism 62: 511-536.

Riegl, A. 1893. Stilfragen: Grundlegungen zu einer Geschichte der Ornamentik. Berlin: George Siemens. 1992. The problems of style. Translated by E. Kain. Princeton, NJ: Princeton University Press.

- 2004. Historical grammar of the visual arts. Translated by J. E. Jung. New York: Zone Books.

Robins, W. 2007. Editing and evolution. Literature Compass 4, no. 1: 89-120.

Roubach, M. 2008. Being and number in Heidegger's thought. London: Continuum.

Ruderman, D. B. 1995. Jewish thought and scientific discovery in early modern Europe. New Haven, CT: Yale University Press.

Rudwick, M. J. S. 1985. The great Devonian controversy: The shaping of scientific knowledge among gentlemanly specialists. Chicago, IL: University of Chicago Press.

Russo, L. 2004. The forgotten revolution: How science was born in 300 BC and why it had to be reborn, Translated by S. Levy. Frankfurt am Main: Springer.

Ryckman, T. 2005. The reign of relativity: Philosophy in physics 1915-1925. Oxford: Oxford University Press.

Sandbothe, M. 1994. Die Verzeitlichung der Zeit: Grundtendenzen der modernen Zeitphilosophie und die aktuelle Wiederentdeckung der Zeit. Glaube und Denken. Jahrbuch der Karl-HeimGesellschaft 7: 108-133. 
Sapp, J. 1990. Where the truth lies: Franz Moewus and the origins of molecular biology. Cambridge: Cambridge University Press.

- 2003. Genesis: The evolution of biology. Oxford: Oxford University Press.

Scerri, E. 2000. Realism, reduction and the 'intermediate position'. In Of minds and molecules, edited by N. Bhushan and S. M. Rosenfeld, 51-72. Oxford: Oxford University Press.

- 2005. Normative and descriptive philosophy of science and the role of chemistry. In Philosophy of chemistry: The synthesis of a new discipline, edited by D. Baird, E. Scerri, and L. McIntyre, 119-128. Dordrecht: Springer.

- 2006. The periodic table: Its story and its significance. Oxford: Oxford University Press.

Schäfer, L. 2006. Autonomy vs. development: Duhem on progress in science. In Revisiting discovery and justification, edited by J. Schickore and F. Steinle, 79-98. Dordrecht: Springer.

Schiebinger, L. 1989. The mind has no sex? Women in the origins of modern science. Cambridge, MA: Harvard University Press.

Schirrmacher, A. 2002. The establishment of quantum physics in Göttingen 1900-24: Conceptional preconditions-Resources-Research politics. In History of modern physics, edited by H. Kragh, G. Vanpaemel, and P. Marage, 295-309. Turnhout: Brepols.

Schleicher, A. 1873. Die Darwinsche Theorie und die Sprachwissenschaft-Offenes Sendschreiben an Herrn Dr. Ernst Haeckel. Weimar: Böhlau; also in Linguistics and evolutionary theory: Three essays by August Schleicher, Ernst Haeckel, and Wilhelm Bleek, edited by E. F. K. Koerner. Amsterdam: John Benjamins, 1983.

Schmied-Kowarzik, W., ed. 1995. Erkennen—Monas—Sprache. Würzbug: Königshausen \& Neumann.

Schrift, A. 2006. Twentieth-century French philosophy: Key themes and thinkers. Malden: MA: Blackwell.

Scholz, E. 2005. Felix Hausdorff and the Hausdorff edition. Newsletter of the European Mathematical Society 55: 23-25.

Schummer, J. 2003. The philosophy of chemistry. Endeavour 27, no. 1:37-41.

Schweber, S. S. 1977. The origin of the Origin revisited. Journal of the History of Biology 10: 229-316.

Secord, J. A. 1986. Controversy in Victorian geology: The Cambrian-Silurian dispute. New Haven, CT: Yale University Press.

- 1991. The discovery of a vocation: Darwin's early geology. British Journal for the History of Science 24: 133-57.

Seigfried, H. 1978. Heidegger's longest day: Being and time and the sciences. Philosophy Today 22: 319-331.

Semper, G. 1860-1863. Der Stil in den technischen und tektonischen Künsten, oder praktische Aesthetik: Ein Handbuch für Techniker, Künstler und Kunstfreunde. 2 vols. Munich: Friedrich Bruchmann.

Shapin, S., and S. Schaffer. 1985. Leviathan and the air-pump: Hobbes, Boyle and the experimental life. Princeton, NJ: Princeton University Press.

Sheehan, H. 1985. Marxism and the philosophy of science: A critical history. Atlantic Highlands, NJ: Humanities Press.

Simons, P. 2004. Open and closed culture: A new way to divide Austrians. In Phenomenology and analysis: Essays on central European philosophy, edited by A. Chrudzimski and W. Huemer, 11-32. Frankfurt am Main: Ontos Verlag.

Sloan, R. 2003. The making of a philosophical naturalist. In The Cambridge companion to Darwin, edited by J. Hodge and G. Radick, 17-39. Cambridge: Cambridge University Press.

Small, R. 2001. Nietzsche in context. Aldershot: Ashgate.

- 2005. Nietzsche and Rée: A star friendship. Oxford: Oxford University Press.

Smith, B. 2006. Why Polish philosophy does not exist. In The Lvov-Warsaw school: The new generation, edited by J. J. Jadacki and J. Paśniczek, 19-39. Amsterdam: Rodopi.

Smith, G. M. 1946. The nature of sexuality in Chlamydomonas. American Journal of Botany 33: 625-630.

Soames, S. 2003. Philosophical analysis in the twentieth century. Princeton, NJ: Princeton University Press. 
Solms-Laubach, F. 2006. Nietzsche and early German and Austrian sociology. Berlin: Walter de Gruyter.

Sorrell, T. 1991. Scientism: Philosophy and the infatuation of science. London: Routledge.

Stack, G. 2005. Nietzsche's anthropic circle: Man, science, and myth. Rochester, NY: University of Rochester Press.

Stegmaier, W. 2002. Ein Mathematiker in der Landschaft Zarathustras. Felix Hausdorf als Philosoph. Nietzsche-Studien 31: 195-240.

—. 2007. Nach Montinari: Zur Nietzsche Philologie. Nietzsche-Studien 36: 80-94.

Stoffel, J.-F. 2002. Le Phénoménalisme problématique de Pierre Duhem. Brussels: Académie royale de Belgique.

Stöltzner, M. 1999. Vienna indeterminism: Mach, Boltzmann, Exner. Synthese 119: 85-111.

- 2009. Gangarten des Rationalen : Zu den Zeitstrukturen der Quantenrevolution. Berichte zur Wissenschaftsgeschichte 32: 176-192.

Thomas, P. 2008. Marxism and scientific socialism: From Engels to Althusser. New York: Routledge.

Thorndike, L. 1941. History of magic and experimental science. New York: Columbia University Press.

Tieszen, R. 2005. Phenomenology, logic, and the philosophy of mathematics. Cambridge: Cambridge University Press.

Tiles, M. 1984. Bachelard: Science and objectivity. Cambridge: Cambridge University Press.

- 2005. Bachelard's non-Cartesian epistemology. In Continental philosophy of science, edited by G. Gutting, 157-175. Oxford: Blackwell.

Timpanaro, S. 2004 [1981]. La genesi del metodo del Lachmann. Torino: UTET.

—. 2006. The genesis of Lachmann's method. Translated by G. Most. Chicago, IL: University of Chicago Press.

Todorov, T. 2003. Hope and memory: Lessons from the twentieth century. Princeton, NJ: Princeton University Press.

Trudeau, R. 2001. The non-Euclidean revolution. Basel: Birkhäuser.

Turner, A. R. 1994. Inventing Leonardo. Berkeley: University of California Press.

Ullmann, D. 1996. Chladni und die Entwicklung der Akustik von 1750-1860. Basel: Birkhäuser.

Uzielli, G. 1894. La vita e i tempi di Paolo dal Pozzo Toscanelli. Rome: Forzani e C. Tipografi del Senato.

Veltman, K. H. 1986. Leonardo da Vinci studies I: Linear perspective and the visual dimensions of science and art. Munich: Deutscher Kunstverlag.

—. 2008. Leonardo da Vinci: A review. Leonardo 41: 381-388.

Venturelli, A., and S. Richter. 2003. Kunst, Wissenschaft und Geschichte bei Nietzsche. Berlin: Walter de Gruyter.

Visvanathan, S. 1988. On the annals of the laboratory state. In Science, hegemony, and violence: A requiem for modernity, edited by A. Nandy, 257-288. Oxford: Oxford University Press.

- 2006. Alternative science. Theory, Culture and Society 23, no. 2-3: 164-169.

Wallace, W. 1990. Duhem and Koyré on Domingo de Soto. Synthese 83: 239-260.

Wedgwood, H. 1866. On the origin of language. London: Trübner.

Weizsäcker, C. F. von. 1999. Nietzsche: Perceptions of modernity. In Nietzsche, epistemology, and philosophy of science: Nietzsche and the sciences, vol. 2, edited by B. Babich and R. S. Cohen, 221-240. Dordrecht: Kluwer.

West, D. 1996. Introduction to continental philosophy. Cambridge, MA: Polity Press.

Wetterstein, J. R. 1982. The philosophy of science and the history of science: Separate domains vs. separate aspects. Philosophical Forum 14: 59-79.

Wigner, E. 1960. The unreasonable effectiveness of mathematics in the natural sciences. Communications in Pure and Applied Mathematics 131: 1-14.

Wölfflin, H. 1932. Principles of art history. Translated by M. D. Hottinger. New York: Dover.

Wolters, G. 1987. Mach I, Mach II, Einstein und die Relativitätstheorie: Eine Fälschung und ihre Folgen. Berlin: Walter de Gruyter. 
1989. Phenomenalism, relativity and atoms: Rehabilitating Ernst Mach's philosophy of science. In Logic, methodology and philosophy of science VIII: Proceedings of the Eighth International Congress of Logic, Methodology and Philosophy of Science, Moscow, 1987, edited by J. E. Fenstad, I. T. Frolov, and R. Hilpinen, 641-660. Amsterdam: North-Holland.

Woodfield, R., ed. 2001. Art history as cultural history: Warburg's projects. Amsterdam: G\&B Arts.

Woods, A., and T. Grant. 2002. Reason in revolt: Marxist philosophy and modern science. London: Wellred.

Worster, D. 1994. Nature's economy: A history of ecological ideas. Cambridge: Cambridge University Press.

Wreen, M. 1988. Admit no force but argument. Informal Logic 10, no. 2: 89-96.

Wright, G. H. 1993. Musil and Mach. In G. H. Wright, The tree of knowledge and other essays. Leiden: Brill, 53-61.

Yates, F. 1991. Giordano Bruno and the hermetic tradition. Chicago, IL: University of Chicago Press.

Yourgrau, P. 2005. A world without time: The forgotten legacy of Gödel and Einstein. New York: Basic Books.

Zahar, E. 2001. Poincaré: From conventionalism to phenomenology. La Salle, IL: Open Court.

Zimmerli, W., and M. Sandbothe, eds. 1993. Klassiker der modernen Zeitphilosophie. Darmstadt: Wissenschaftliche Buchgesellschaft. 